NBER WORKING PAPER SERIES

\title{
IMPACT OF BILINGUAL EDUCATION PROGRAMS ON LIMITED ENGLISH PROFICIENT STUDENTS AND THEIR PEERS: REGRESSION DISCONTINUITY EVIDENCE FROM TEXAS
}

\author{
Aimee Chin \\ N. Meltem Daysal \\ Scott A. Imberman \\ Working Paper 18197 \\ http://www.nber.org/papers/w18197 \\ NATIONAL BUREAU OF ECONOMIC RESEARCH \\ 1050 Massachusetts Avenue \\ Cambridge, MA 02138 \\ June 2012
}

We thank Chinhui Juhn, Danielle Li, and workshop participants at the 2010 and 2011 National Academy of Education Annual Meeting, 2011 ASSA Meetings, and 2012 SOLE Meetings for helpful comments and discussion. Imberman gratefully acknowledges financial support from the National Academy of Education/Spencer Foundation Postdoctoral Fellowship. A University of Houston Small Grant was used to purchase the data, for which we are grateful. The authors bear sole responsibility for the content of this paper. The views expressed herein are those of the authors and do not necessarily reflect the views of the National Bureau of Economic Research.

NBER working papers are circulated for discussion and comment purposes. They have not been peerreviewed or been subject to the review by the NBER Board of Directors that accompanies official NBER publications.

(C) 2012 by Aimee Chin, N. Meltem Daysal, and Scott A. Imberman. All rights reserved. Short sections of text, not to exceed two paragraphs, may be quoted without explicit permission provided that full credit, including $(\mathbb{C}$ notice, is given to the source. 
Impact of Bilingual Education Programs on Limited English Proficient Students and Their Peers: Regression Discontinuity Evidence from Texas

Aimee Chin, N. Meltem Daysal, and Scott A. Imberman

NBER Working Paper No. 18197

June 2012

JEL No. I21,J24

\section{ABSTRACT}

Texas requires a school district to offer bilingual education when its enrollment of limited English proficient (LEP) students in a particular elementary grade and language is twenty or higher. Using school panel data, we find a significant increase in the probability that a district offers bilingual education above this 20 -student cutoff. Using this discontinuity as an instrument for district bilingual education provision, we find that bilingual education programs do not significantly impact the standardized test scores of students with Spanish as their home language (comprised primarily of ever-LEP students). However, there are significant positive spillover effects to their non-LEP peers.

Aimee Chin

University of Houston

Department of Economics

204 McElhinney Hall

Houston, TX 77204-5019

and NBER

achin@uh.edu

N. Meltem Daysal

Department EOR

Tilburg University

Warandelaan 2

P.O. Box 90153

5000 LE Tilburg

The Netherlands

meltem.daysal@uvt.nl
Scott A. Imberman

Michigan State University

486 W. Circle Drive

110 Marshall-Adams Hall

East Lansing, MI 48824-1038

and NBER

imberman@msu.edu 


\section{Introduction}

One of the major challenges facing educators and policymakers today is the large and growing number of limited English proficient (LEP) children in U.S. public schools. About 1 in 9 students enrolled in pre-kindergarten to grade 12 were classified as LEP in 2008-09, a marked increase from the ratio of 1 in 13 recorded one decade earlier (National Clearinghouse for English Language Acquisition 2011). These LEP students are present not only in big cities and other traditional immigrant-receiving areas, but across the country; even by 2001-02, when U.S. immigrants were less geographically dispersed than they are today, about half of public schools in the U.S. had at least one LEP student (Zehler et al. 2003). Lack of proficiency in English presents a significant barrier to learning in U.S. schools, and given these recent trends in LEP student population and geographic dispersion, how to educate LEP students is likely to remain an important policy issue in the coming years.

School districts are required by federal law to provide special assistance to LEP students. ${ }^{1}$ Bilingual education (BE) and English as a Second Language (ESL) are the two most common educational programs offered by school districts to help LEP students. While there is considerable variation in how these programs are implemented in the classroom, a defining feature of BE is the use of the student's native language for at least some of the academic instruction; other programs such as ESL teach only in English. Given this feature, LEP students participating in BE tend to be placed in a self-contained classroom with classmates who share the same home language and a dedicated bilingual education teacher who can teach in that language. In contrast, LEP students participating in ESL tend to be placed in mainstream classrooms with pullout time with an ESL teacher to improve their English skills.

In this paper, we identify the causal effect of BE on the academic achievement of LEP students and their non-LEP peers using quasi-experimental variation in $\mathrm{BE}$ exposure generated by a policy rule governing the provision of bilingual education

\footnotetext{
${ }^{1}$ The relevant laws are Title VI of the 1964 Civil Rights Act and the Equal Educational Opportunity Act of 1974. Section II.A provides a legislative background on educational programs for LEP students.
} 
programs in Texas. The policy rule requires a school district to offer BE when its enrollment of LEP students in a particular elementary grade level and language is twenty or higher. Below this 20-student cutoff, school districts are free to offer BE or ESL, with most choosing to offer ESL. ${ }^{2}$ This suggests a regression discontinuity (RD) design in which the effect of BE (relative to ESL) on student achievement can be obtained by comparing student outcomes in districts just above the 20 -student cutoff (and therefore more likely to provide BE) and student outcomes in districts just below the cutoff. We elaborate on this RD strategy in Section III.

This paper adds to a large literature evaluating educational programs for LEP students, which we briefly summarize in Section II.B. It addresses two major gaps in this literature. First, this literature has focused exclusively on the impacts on the intended beneficiaries themselves (i.e., the LEP students) and ignored any effects that these programs might have on non-LEP students. Yet, because these programs change the student composition of mainstream classrooms and school resource allocations, among other things, it is reasonable to believe that there might be spillover effects to non-LEP students. To our knowledge, our study is the first to test for spillover effects of educational programs for LEP students, and to the extent that they exist, to quantify them. Quantifying these spillover effects is necessary for a complete cost-benefit analysis of the various educational programs for LEP students; all else equal, policy makers might prefer the program that benefits non-LEP students more (or, stated differently, harms non-LEP students less).

Second, most of the studies in this literature do not address the potential problem of endogeneity in student exposure to the educational programs for LEP students. In general, student exposure to a program is not random, and instead is the result of decisions made by students, parents, schools and districts. Thus, it is likely correlated with unmeasured and unobserved characteristics of the students, parents, schools and districts, some of which might in turn be correlated with student

\footnotetext{
${ }^{2}$ There are cost advantages to only offering ESL, as we discuss in Section IV.A.
} 
achievement. Estimates of program effects that do not take this into account tend to be biased. Our research adds to the small handful of studies that provide estimates of the impacts of educational programs for LEP students with a causal interpretation. ${ }^{3}$

We implement our RD strategy using panel data on elementary schools in districts near the 20-Spanish-LEP-student cutoff defined by the policy rule. We describe these data in Section IV. We restrict our attention to the policy rule vis-à-vis Spanish LEP students for a practical reason: Spanish is the home language of 90 percent of Texas' total LEP enrollment, and is the only language for which there is enough variation across districts to implement our empirical strategy. Due to this restriction, our results pertain to the effect of district provision of Spanish bilingual education programs (relative to providing only ESL for Spanish LEP students). However, considering that Spanish is the language of over three-quarters of total LEP enrollment in the U.S. and accounts for an even higher share of bilingual education programs operating in the U.S. (Zehler et al. 2003), it is especially policy-relevant to understand the effects of Spanish BE programs.

To preview the results, we find evidence of a significant increase in the probability that a district offers bilingual education above the 20-Spanish-LEP-student cutoff. We do not find any significant jumps at the cutoff in covariates unrelated to BE provision, nor do we observe "stacking" of districts below the cutoff (which would have raised concerns about district manipulation to avoid providing $\mathrm{BE}$ ), which validates the interpretation of differences in student outcomes just above and just below the cutoff as due to district BE provision.

We proceed by using the variation in district provision of BE induced by the policy rule as an instrumental variable to identify the causal impact of district provision of $\mathrm{BE}$ on student achievement. These instrumental variable estimates provide the local average treatment effect of district provision of Spanish BE among school districts whose decision to offer Spanish BE is constrained by the policy rule.

\footnotetext{
${ }^{3}$ These studies include Slavin et al. (2010), Matsudaira (2005) and Angrist, Chin and Godoy (2008), which we summarize in Section II.B.
} 
Our main findings are as follows. First, district provision of BE significantly raises the standardized test scores of students who are non-LEP and whose home language is not Spanish. These students would never have been candidates to participate in Spanish $\mathrm{BE}$ programs, thus this finding is indicative of program spillover effects.

Second, district provision of $\mathrm{BE}$ has generally positive but smaller and statistically insignificant effects on all students whose home language is Spanish taken together. In our sample, 89 percent of Spanish home language students are classified as LEP in first grade, indicating that this sample primarily consists of those who would have been eligible to participate in educational programs for Spanish LEP students. Hence, our results suggest that the impact of district bilingual education provision on the intended beneficiaries is not different from zero.

Finally, we find that district BE provision significantly increases test scores on all students taken together. The positive net impact indicates that on average, the test score gains due to district $\mathrm{BE}$ provision exceed test score losses experienced by students in a given cohort and school.

The foregoing estimation results, along with robustness checks and an exploration of some potential mechanisms for the spillover effects, are reported in Section V. Section VI concludes and discusses some policy implications.

\section{Background and Related Literature}

\section{A. Legislative Background on Educational Programs for LEP Students}

The Bilingual Education Act passed in 1968 was the first federal law expressly addressing the educational needs of LEP students in American schools, and did so by providing a financial reward-federal grants awarded on a competitive basis-for providing help to LEP students. ${ }^{4}$ Later federal laws made it a legal responsibility of school districts to provide such help. The two main pieces of legislation are the Title VI of the 1964 Civil Rights Act, which prohibits discrimination on the basis of race,

\footnotetext{
${ }^{4}$ This legislation was Title VII of the Elementary and Secondary Education Act. Crawford (1989) provides a good history of BE in the U.S., and Nieto (2009) provides a more recent summary.
} 
color or national origin in federally-assisted programs, and the Equal Educational Opportunity Act of 1974, which basically extends Title VI to school districts not receiving federal funds. School districts faced termination of funding from the U.S. Department of Education or private lawsuits if they failed to provide LEP children with an equal educational opportunity.

The U.S. Supreme Court's Lau v. Nichols decision in 1974 made clear that the prevalent practice of "sink or swim" instruction, in which LEP students are placed in the same classrooms as non-LEP students without additional services, was a violation of LEP students' civil rights. To receive an equal educational opportunity, LEP students were entitled to special assistance. Guidelines on Title VI compliance issued by the Department of Education to school districts in 1970 called for "affirmative steps" new guidelines in 1975 specified bilingual education.

In an environment that demanded Title VI compliance, individual states passed laws mandating bilingual education programs for LEP students. Massachusetts was the first, with a 1971 law, followed by Alaska (1972), California (1972), Illinois (1973), Texas (1973), New York (1974), and others. The programs mandated by these laws tended to be transitional BE programs, which have the goal of mainstreaming the LEP students as soon as they acquire sufficient English-language skills; native language instruction is temporarily used so that the LEP students can keep up in academic subjects. ${ }^{6}$ Additionally, these laws did not require every school district to provide bilingual education to every LEP student. Instead they specified the circumstances under which a school district would provide BE, and these circumstances generally involved the number and concentration of LEP students of a particular grade and of a particular language group in a school district. For example, in Texas, school districts with at least twenty LEP students in a particular elementary grade and language must

\footnotetext{
535 Fed. Reg. 11,595 (1970) as cited in U.S. Commission on Civil Rights (1995), p. 71.

${ }^{6}$ Dual language programs, whose goal is proficiency in both English and the student's home language, are rare in the U.S. and not the subject of this study.
} 
offer bilingual education. Below, we take advantage of this policy rule in Texas to identify the effects of bilingual education.

Since the late 1990s, there has been a shift away from using bilingual education toward using English-only programs to help LEP students. Revealingly, in 2002, the Bilingual Education Act was renamed the English Language Acquisition, Language Enhancement, and Academic Achievement Act (Title III of the No Child Left Behind Act). Also, several states eliminated bilingual education in public schools through ballot initiatives: California (1998), Arizona (2000) and Massachusetts (2002). Reflecting this shift, 40 percent of LEP students in U.S. public schools were in a BE program in 2001-02, compared to 63 percent in 1991-92 (the remainder are in English-only programs, with the largest being ESL) (Zehler et al. 2003).

To comply with U.S. civil rights laws, school districts must provide special assistance to LEP students, but neither history nor existing evaluations (which we discuss in the next subsection) provide clear guidance for which programs are more effective. This study contributes to the debate on how to help LEP students by providing new empirical evidence on the effects of bilingual education program provision (compared to ESL program provision alone); it is at this very margin-BE or ESL — that many school districts are making policy decisions today.

\section{B. Related Literature}

There is a substantial body of research evaluating the effect of educational programs for LEP students on the LEP students themselves. ${ }^{7}$ Most of these papers do not address the potential problem of endogeneity in program exposure. A few recent studies use research designs that are more convincing for identifying causal relationships. Slavin et al. (2010) conduct a randomized evaluation in which 387 LEP kindergartners in ten schools were randomly assigned (within school) to either bilingual education or structured English immersion (an English-only approach). They

\footnotetext{
${ }^{7}$ See, for example, Baker and de Kanter (1981), Willig (1985), Rossell and Baker (1996) and Greene (1998) for reviews. Slavin et al. (2010) offer a more recent discussion of this literature.
} 
find no significant differences in tests measuring English skills by fourth grade. Matsudaira (2005) uses a regression-discontinuity design taking advantage of a district policy rule governing which students are classified as LEP and therefore eligible to participate in educational programs for LEP students (which in this district is BE or ESL). He finds little difference in academic achievement between students who scored just below the English skills assessment cutoff (and eligible for BE/ESL services) and just above (ineligible, so placed in mainstream classrooms). Angrist, Chin, and Godoy (2008) look at policy shifts in Puerto Rico that changed the medium of instruction from English to Spanish and find no impact on English-speaking ability in adulthood. These three studies suggest that, while not helping LEP students, pedagogical approaches using native language instruction do not seem to hurt them either. Our study contributes by exploiting a different source of exogenous variation in exposure to educational programs for LEP students.

A notable gap in the literature evaluating LEP programs is that it ignores potential impacts of these programs on non-LEP students. To our knowledge, our study is the only one to examine potential effects of educational programs for LEP students on non-LEP peers. Closely related, though, are Cho (2011) and Geay, McNally and Telhaj (2011), which estimate the impact of LEP students on non-LEP peers. These studies are pertinent to ours because as we discuss in Section IV.A, one channel through which BE provision may impact non-LEP students is through decreasing the exposure of non-LEP students to LEP students. Cho uses withinschool, and sometimes within-student, variation in having an LEP classmate in the Early Childhood Longitudinal Study, Kindergarten Cohort dataset, and finds that having at least one LEP classmate is associated with lower reading test score gains but no significant differences in math test score gains. Geay et al. exploit variation in share of classmates who are non-native English speakers arising from within-school cohort-to-cohort fluctuations, as well as from European Union enlargement, and find no significant effects of exposure to non-native English speakers on the achievement of native English speakers in England. 
Although few studies examine peer effects of LEP students on non-LEP students specifically, there exists a large literature on peer effects in education. Two strands within this literature are especially related to our study. One strand is on peer effects in primary and secondary education, including on the effect of being exposed to peers who have higher or lower achievement test scores (e.g., Angrist and Lang 2004; Hanushek, Kain, Markman and Rivkin 2003; Hoxby and Weingarth 2006; Lavy, Paserman, and Schlosser 2012; Imberman, Kugler, and Sacerdote 2012) or who exhibit disruptive behavior (e.g., Figlio 2005; Aizer 2008; Carrell and Hoekstra 2010). A second strand is on the impact of immigrants on the educational outcomes of natives (e.g., Betts 1998; Hoxby 1998; Liu 2000; Neymotin 2009). Since many immigrants are LEP when they first enter school in the U.S., these studies are relevant. However, it should be noted that only half of LEP students enrolled in U.S. public schools are foreign-born, and many immigrant students are not LEP, thus the impact of LEP students may well differ from the impact of immigrant students.

\section{Empirical Strategy}

\section{A. Conceptual Framework}

The direction of the impact of BE programs (compared to ESL programs) on academic achievement is theoretically ambiguous for both LEP and non-LEP students. LEP students are the students eligible to participate in BE and ESL. BE and ESL are the two most common programs offered by schools to address the learning needs LEP students, and each has advantages and disadvantages. For example, native language instruction might delay English acquisition, but it might also enable LEP students to better keep up in math and other academic subjects while they are learning English. On the other hand, an English-only approach like ESL might improve learning in both English and other subjects by reallocating time that would have been spent on teaching LEP students the ability to read and write in their native language.

Non-LEP students do not participate in BE or ESL themselves, but they may experience spillover effects from these programs. The nature of these spillover effects 
likely differs by program. One reason is that the two programs result in dramatically different distributions of LEP students across classes within a grade. Mainstream classes have fewer LEP students when BE is offered because LEP students in BE tend to be grouped together to form a separate class while LEP students in ESL are in the same classes as non-LEP students (with ESL instruction provided on a pull-out basis, or with an in-class ESL aide). Exposure to LEP students in class could impact nonLEP students' academic performance through a number of mechanisms. First, teachers with LEP students in their classes may need to provide extra assistance to these students, which would take time away from other students. Second, LEP students may be more prone to disruption due to frustration from difficulties understanding the material taught in English. Third, to the extent that achievement among LEP students is lower than the non-LEP students, there could be an achievement peer effect which could worsen non-LEP outcomes. For example, the content may be taught at a lower level to reach the weaker students. Nonetheless, there are also reasons to think that exposure to LEP students may be helpful. For example, LEP students may be more advanced along some dimensions (e.g., certain subjects, or in terms of some noncognitive skills) that might generate positive peer effects.

Besides changes in class composition, another way BE programs could generate differential spillover effects to non-LEP students is through the school budget. Whether BE or ESL is more costly for the school district depends on a number of factors, including the number of LEP students and their distribution across languages and grades. When the school district has few LEP students in the same language and grade, BE programs tend to be more expensive than ESL programs. Since a BE teacher is typically attached to a specific class on a full-time basis (serving LEP students of a common home language and grade), there is little possibility for schools to spread the cost of a BE teacher over LEP students of different home languages and grades as they could with an ESL teacher. Thus, to pay for BE, schools may have to reallocate resources, and this may impact non-LEP students' academic performance. While a simple story of BE programs crowding out programs for non- 
LEP students might suggest negative effects, in fact schools may offset the higher costs with additional revenues, so these resource effects are ambiguous in direction.

\section{B. Identification Strategy}

Given the foregoing considerations, how bilingual education program provision affects student academic achievement is ultimately an empirical question. Thus we turn to our estimation strategy. We wish to estimate the effect of exposure to bilingual education programs on achievement, which might be approximated as:

$$
y_{i d c g}=\alpha+\beta B E_{d c}+X_{i d c g} \pi+\varepsilon_{i d c g}
$$

for student $i$ in school district $d$ who is a member of first grade cohort $c$ and observed at grade $g . y$ is a student academic achievement measure, $B E$ is an indicator for the student's school district providing a bilingual education program, $X$ is a set of student, school and district characteristics, and $\varepsilon$ is the error term. The parameter of interest is $\beta$, which is the effect of student exposure to bilingual education. Note that the measure of exposure expressed in Equation 1 is not at the individual level, but at the districtcohort level. This is natural when we use data on non-LEP students, who are never participants in BE programs but nevertheless could experience spillover effects from them if their school district offers it to their classmates. LEP students, on the other hand, are eligible to participate in BE programs if their school district offers it to their cohort but may choose not to take it up; thus, by using this district-cohort level measure of $\mathrm{BE}$ availability, we are capturing an intention-to-treat effect for LEP students rather than the effect of participation in BE. Focusing on potential exposure to $\mathrm{BE}$, rather than actual take-up of $\mathrm{BE}$, circumvents issues concerning non-random selection of individuals into BE programs. Moreover, the intention-to-treat effect is of direct interest for policy making, as school districts can only control whether to offer $\mathrm{BE}$ - students cannot be forced to participate in BE.

Nevertheless, even the more aggregate measure of BE exposure used in Equation 1 might be endogenous. It is not random which school districts offer 
bilingual education; for example, they may be the ones with more LEP students, more growth in LEP students, more wealth, LEP students with especially low English proficiency, etc. Thus, estimates of $\beta$ using ordinary least squares (OLS) are unlikely to provide the causal effect of student exposure to a bilingual program, and a priori we cannot even sign the direction of the bias. To address this endogeneity problem, we use a regression-discontinuity approach that exploits a policy rule the provision of $\mathrm{BE}$ in Texas. The State of Texas mandates provision of bilingual education in a given language and elementary grade by a school district when the district-wide population of LEP students in that language and elementary grade is greater than or equal to $20 .^{8}$

Essentially, our empirical strategy is to compare student outcomes in districts that have slightly less than 20 LEP students in a language-grade to those with slightly more. In practice, we focus only on the policy rule vis-à-vis Spanish LEP students, who represent about 90 percent of Texas' total LEP enrollment, because Spanish is the only language group for which there is enough variation across districts to implement our empirical strategy. ${ }^{9}$ It is unlikely that districts with 19 Spanish LEP students differ that much from districts with 20 Spanish LEP students, but due to the policy rule, the latter districts must offer bilingual education, and we can take the difference in outcomes between the districts with 20 and districts with 19 to learn about the effect of district BE provision. This example is meant to be illustrative only, as limiting our analysis to only those districts with exactly 19 or 20 Spanish LEP students would lead to very imprecise estimates. In implementing our empirical strategy therefore, we expand the neighborhood around the cutoff. With the wider bandwidth, it becomes possible that there exists a relationship between the number of Spanish LEP students and the outcome that is not solely due to the policy rule, so it is necessary to control

\footnotetext{
${ }^{8}$ This rule is part of Texas Administrative Code, Title 19, Part 2, Chapter 89, Subchapter BB, Rule $\$ 89.1205$ (Commissioner's Rules Concerning State Plan for Educating Limited English Proficient Students).

${ }^{9}$ In contrast, LEP students with other home languages are both fewer and more concentrated, leaving too few observations of districts near the 20 -student cutoff for a particular language and grade. The Spanish share of LEP students in 2001-02 is 77 percent in the U.S. (Zehler et al. 2003); given Texas' proximity to Mexico and Central America, it is not surprising that its Spanish share is somewhat higher.
} 
for the number of Spanish LEP students. We therefore estimate the following equation to study the impact of the policy rule on district BE provision:

$$
B E_{d c}=\alpha_{1}+\delta_{1} \text { Above } 20_{d c}+f\left(\text { LEP_Count }_{d c}\right)+X_{1 i d c g} \pi_{1}+\varepsilon_{1 i d c g}
$$

for student $i$ in school district $d$ who is a member of first grade cohort $c$ and observed at grade $g . B E$ is an indicator for the student's school district offering a bilingual education program, LEP_Count is the district-wide Spanish LEP student count for student $i$ 's first grade cohort, Above20 is an indicator for LEP_Count being greater than or equal to 20, $f($ LEP_Count $)$ is a function of LEP count ${ }^{10}$, and $X_{1}$ is a set of student, school and district characteristics.

Below, we find that $\delta_{1}$ is positive and statistically significant, indicating that the policy rule induced some districts that otherwise would not have provided BE to provide BE. We proceed by instrumenting the potentially endogenous regressor in Equation 1, BE, with Above2O (where $X$ in Equation 1 is comprised of $X_{1}$ and $\left.f\left(L E P \_C o u n t\right)\right)$ in order to obtain an estimate of $\beta$ with a causal interpretation. This strategy is often referred to as a fuzzy regression discontinuity design (Imbens and Lemieux 2008; Lee and Lemieux 2010). The first-stage equation associated with the 2SLS estimation of Equation 1 is given by Equation 2.

Below we also report the results of estimating the reduced-form equation,

$$
y_{i d c g}=\alpha_{R F}+\delta_{R F} \text { Above } 20_{d c}+f\left(L E P \_ \text {Count }_{d c}\right)+X_{1 i d c g} \pi_{R F}+\varepsilon_{R F}{ }_{i d c g}
$$

The reduced-form effect of being just above the 20 -student cutoff, $\delta_{R F}$, indicates the effect of increasing the likelihood of a school district offering BE on achievement. It is desirable to rescale this reduced-form effect to obtain the interpretation of the effect of school district provision of BE, which is what is given by the 2SLS estimate of $\beta$.

The fuzzy RD strategy identifies the local average treatment effect (LATE) for school districts close to the 20-student cutoff. These school districts tend to be smaller, be less urban and (of course) have fewer LEP students. Thus, the effect of district BE provision on academic achievement estimated in this study may not reflect the average

\footnotetext{
${ }^{10}$ Specifically, we use a linear function that allows for different slopes above and below the cutoff.
} 
treatment effect or generalize to larger districts. However, since few studies exist that convincingly identify the causal effects of educational programs for LEP students (and none of these consider spillover effects to non-LEP students), our new evidence is of interest even if it is estimating a LATE. Additionally, we believe this LATE is per se interesting because a majority of school districts in the U.S. with any LEP students have relatively small LEP enrollments. In 2001-02, about 43 percent of school districts in the U.S. had at least one LEP student (Zehler et al. 2003). 2.6 percent of school districts with LEP students enrolled 5000 or more LEP students, collectively accounting for 54 percent of the total number of LEP students in the U.S., thus the vast majority of school districts with LEPs are contending with some, but not many, LEP students. As immigrants increasingly settle outside of traditional immigrant-receiving places, the number of these low-LEP-enrollment school districts will continue to grow.

\section{Data}

To implement our RD strategy, we use publicly-available data on the standardized test scores and demographic characteristics of students enrolled in Texas public elementary schools. ${ }^{11}$ To maintain data confidentiality, the Texas Education Agency provided us with grouped student data rather than individual-level student data. In particular, we obtained mean data at the school-grade-year level for three mutually exclusive categories of students: (1) students who are not classified as LEP and do not have Spanish as their home language (below, we refer to them as the "nonLEP, non-Spanish home language" students, and we refer to the dataset containing these students' test scores as the "non-LEP, non-Spanish home language" sample); (2) students who have Spanish as their home language (analogously, the "Spanish home language" students and sample) $)^{12}$; and (3) remaining students. Below, we estimate Equations 1-3 separately for the first two categories of students, as well as for all

\footnotetext{
${ }^{11}$ We obtained the test score data through a public information request to the Texas Education Agency.

${ }^{12}$ The "Spanish home language" designation is based on a home language survey that parents fill out when their child first enrolls in a district. This is not the same as Hispanic status, as there are many Hispanics who do not use Spanish at home.
} 
students combined, where $i$ in these equations now indexes school rather than the individual student. ${ }^{13}$ Note that the policy variation we are exploiting is at the districtgrade-year level, thus our data are at a less aggregate level than the policy. ${ }^{14}$

The "non-LEP, non-Spanish home language" category is comprised of students who would never have been in educational programs for Spanish LEP students, so effects of district BE provision estimated using data on these students only reflect spillover effects of the Spanish LEP programs. The "Spanish home language" category is comprised of students who are currently LEP, formerly LEP (but since mainstreamed) and never LEP, so in theory, effects estimated using these students reflect both the effect of Spanish BE programs on the individuals who were eligible to participate in Spanish LEP programs (i.e., the intended beneficiaries) as well as spillover effects. In practice though, 89 percent of "Spanish home language" students are classified as LEP in first grade in our analysis sample, ${ }^{15}$ so results using data on these students reflect the effects of BE provision on the intended beneficiaries. Finally, the results using data on all students reflect the net effect of the Spanish BE programs.

To assess whether the policy rule is binding, we must examine whether the probability of a district providing $\mathrm{BE}$ increases at the 20-student cutoff. In our empirical work below, we use the counts of Spanish LEP students from first grade as the relevant counts for determining district BE provision. Two points are worth noting. First, in our data, the Spanish LEP student count for a particular school-year-grade cell is masked if the number is between 1 and 4 . In our main analysis, we assigned the average value of 2.5 to those school-grade-year cells with masked values. ${ }^{16}$ Second,

\footnotetext{
${ }^{13}$ The average across all students for a given school-grade-year is the weighted average across the three categories (weighted by the number of students in each category). For the school districts near the 20Spanish-LEP-student cutoff, the third category (LEP students with a language other than Spanish as the home language) is very small-accounting for less than five percent of school enrollment - thus we do not consider this student category separately.

${ }^{14}$ Although we described the policy variation as occurring at the level of district-cohort in Section III.B, this statement is also accurate because year and grade data are used to construct cohort data.

${ }^{15}$ In the full sample, without the restriction to small districts near the 20-Spanish-LEP-student cutoff, 78 percent of Spanish home language students are classified as LEP in first grade.

${ }^{16}$ Our results are robust to alternative ways of treating the masked values, as we show in Section V.G.
} 
LEP status is temporary, with LEP students exiting LEP status once they have learned English. ${ }^{17}$ Consider a district with 20 Spanish LEP students in a first grade class and hence offers bilingual education. By the time these students reach third grade, there will likely be fewer than 20 Spanish LEP students in the cohort due to mainstreaming of initially LEP students who become proficient in English (and therefore, exit LEP status). Nonetheless, even though the LEP count falls, the district would most likely still provide bilingual education. ${ }^{18}$ Given that in practice, if a given first grade cohort qualifies for $\mathrm{BE}$, the district commits to providing it for several years, it is appropriate to use the district Spanish LEP count in the first grade class for a student's cohort rather than concurrent LEP counts.

Because the policy rule specifies a 20-student cutoff, we restrict the data to districts near this cutoff. Our main analysis uses observations in districts with 8 to 39 Spanish LEP students in a given first-grade cohort. ${ }^{19}$ We further restrict the data to smaller districts, which we define as districts with total first-grade enrollment fewer than 200 in the 2004-05 school year, in order to form a sample of districts for which the policy rule is likely to bind. ${ }^{20}$ We also do not weigh our regressions by enrollment, as our variation is at the district-grade-year level. Figure 1 maps the districts satisfying our sample criteria using the average Spanish LEP counts in the district during the sample period, and indicates that the districts in our sample are located all over Texas, and that districts above the cutoff are often located next to districts below the cutoff.

\footnotetext{
${ }^{17}$ Due to mainstreaming, LEP status drops off considerably as students age. Using data on LEP counts by grade and district acquired from the Texas Education Agency, we observe that LEP share of enrollment in Texas fall from 11 percent in kindergarten and $1^{\text {st }}$ grade to only 4 percent by $8^{\text {th }}$ grade.

${ }^{18}$ Texas supports a transitional BE program where LEP students are moved to mainstream classes once they acquire sufficient English skills. Typically students stay in BE several years before attaining the English skills to be mainstreamed, and so the district typically commits to providing BE to this cohort for this duration.

${ }^{19}$ We show in Section V.G that our results are robust to using other bandwidth selections.

${ }^{20}$ Larger school districts have more resources, and tend to offer bilingual education services even below the cutoff, thus they are less responsive to the policy. Regarding the use of 2004-05 enrollments to define district size, in fact we have used first grade enrollment totals from other years to define the set of districts to be included, and our empirical results are unchanged, as we show in Section V.G. We do not impose the 200 cap on every year for sample inclusion because changes in school enrollment can be endogenous to student achievement.
} 
This provides some reassurance that on the basis of geographic location, the districts just above and just below the cutoff are comparable. We provide more formal analysis of the comparability of districts above and below the cutoff in Section V.B.

Our student outcome measures are standardized test performance for 2002-03 through 2009-10, aggregated to the school-grade-year-student category level. The Texas Assessment of Knowledge and Skills (TAKS) math and reading tests were introduced in 2002-03 (replacing the Texas Assessment of Academic Skills), and to avoid combining student achievement measures based on different tests, we do not use earlier test score data. Students are tested beginning third grade, and our policy rule concerns BE provision in elementary schools, thus we have three grades with test score outcomes: third, fourth and fifth. We link test takers to their first grade cohort's district-wide number of Spanish LEP students and district-wide provision of bilingual education, so we are using demographic data for 1998-99 to 2007-08. ${ }^{21}$

We use three measures of test performance for each subject, with the intention of capturing effects at different parts of the student academic achievement distribution. The mean standardized scale score, which is the average test score normalized to standard deviation units using the state-wide mean and standard deviation, captures movements in test scores for all parts of the distribution. The passing rate, which is the percent of students that met the minimum passing standard set by the State Board of Education, captures movements in test scores for students at the margin of passing/failing. The commended rate, which is the percent of students that met a much higher passing standard (on average, only the top third of passers satisfy this), captures movements in test scores for higher-achieving students. Table 1 provides the means and standard deviations of the variables for the "non-LEP, non-Spanish home language" sample overall and separately for those above and below the cutoff. ${ }^{22}$

\footnotetext{
${ }^{21}$ Thus, for the third, fourth and fifth graders observed at year $\mathrm{t}$, we assign the first grade district-wide Spanish LEP count from year t-2, $\mathrm{t}-3$ and $\mathrm{t}-4$, respectively. For example, for fifth grade test takers in 2002-03, first grade cohort characteristics are taken from 1998-99.

${ }^{22}$ Summary statistics are about the same for variables other than the achievement variables for the other two datasets we use below, the "Spanish home language" sample and the "all students" sample. The
} 


\section{Results}

\section{A. Ordinary Least Square Estimates of the Effect of Bilingual Education}

In Table 2, we present the results from estimating Equation 1 using OLS using the same three samples that we use below to implement our RD strategy. ${ }^{23}$ The OLS coefficients for district BE provision are not significantly different from zero using the "non-LEP, non-Spanish home language" sample (Panel A), which if interpreted causally would indicate no spillover effects for BE programs. In Panel B, the OLS coefficients are negative, and sometimes significant at the 10 percent level, which if interpreted causally would indicate harmful effects of BE for Spanish home language students on net. The estimated effect for all students is shown in Panel C; because about three quarters of all students are in the "non-LEP, non-Spanish home language" category, Panel C estimates are close to those reported in Panel A.

These estimated coefficients for district provision of $\mathrm{BE}$ are unlikely to have a causal interpretation, however, for reasons discussed above. We present the OLS estimates to provide a counterpoint to the instrumental variables estimates of the effect of district provision of $\mathrm{BE}$ discussed below, which we find to be more positivepositive and significant for "non-LEP, non-Spanish home language" students and all students, and not different from zero (but typically positive) for "Spanish home language" students. Comparing the IV estimates to the OLS estimates reveals that the OLS estimates in Table 2 tend to be downward biased. That is, districts that are observed to provide $\mathrm{BE}$ are worse in unmeasured/unobserved dimensions that positively correlate with student test performance.

\section{B. Tests of the Validity of the Regression Discontinuity Design}

Because BE programs tend to be more expensive than ESL programs, and especially because a school district mandated by the Texas policy rule to provide $\mathrm{BE}$

means of the achievement variables are lower for the "Spanish home language" students. These additional tables are available from the authors.

${ }^{23}$ Results based on the full sample, without the restriction to small districts near the 20-Spanish-LEPstudent cutoff, are similar to these results based on the analysis samples. 
also tends to provide ESL (because some parents do not wish to enroll their children in $\mathrm{BE}$ even when it is available), there is a financial incentive for school districts to manipulate their enrollment or LEP classifications to avoid having to provide BE. If school districts have a great deal of control over the number of students categorized as LEP, then students on one side of the 20-student cutoff could be systematically different from those on the other side, invalidating the RD design.

In order to test this, we first provide a visual check by plotting in Figure 2 the distribution of district first grade Spanish LEP students. A discontinuity in the density of school districts around the 20-student cutoff would suggest manipulation of our running variable (McCrary 2008). As the figure shows, there are no irregular heaps in the density of district first grade LEP counts. ${ }^{24}$ In particular, the number of districts declines smoothly as the number of Spanish LEP students increases. Therefore it does not appear that districts manipulate LEP student numbers to avoid providing BE.

Next, we check whether there are differences in observable characteristics across the 20-student cutoff. Figure 3 graphs the mean covariate by number of Spanish LEP students in the first grade cohort for all students in the same school-grade-year cells as the students whose test scores we analyze below. These covariates include gender, race, economic disadvantage (free or reduced lunch), enrollment in gifted and special education programs, and total grade enrollment. For all covariates, the figures show smooth distributions around the cutoff point. More formally, we estimate Equation 3 using each of these observable characteristics as the dependent variable. These results are reported in Panel A of Table 3, and confirm the visual evidence in Figure 3-there are no changes in covariates at the cutoff that are statistically significant at the 5 percent level and only one at the 10 percent level. In order to combine these multiple tests into a single test statistic, we also estimate a Seemingly Unrelated Regression and perform a Chi-squared test for the hypothesis that the

\footnotetext{
${ }^{24}$ More formally, we test whether there is a significant change in the density of Spanish LEP students at the 20 -student cutoff and do not find any. The coefficient on Above 20 is -0.06 (s.e. 0.15).
} 
coefficient of Above 20 are jointly equal to zero across these regressions. The p-value from this test, reported below the regression estimates, is 0.17 .

Since we estimate effects on different categories of students below, we conduct similar tests at the level of school-grade-year-student category, though it should be noted that fewer variables are available. Panels B and C of Table 3 show the results for "non-LEP, non-Spanish home language" students and "Spanish home language" students, respectively. There is no evidence of discontinuities in share of these students who are female, economically disadvantaged or in gifted programs.

Overall, these results indicate that there are no discontinuities in the underlying characteristics of the students. This supports the interpretation that observed discontinuities at the 20-student cutoff are only due to the policy rule governing BE provision, and not to differential student composition above and below the cutoff.

\section{The Discontinuity in District Provision of Bilingual Education}

If the Texas policy rule governing BE provision is binding, then we should observe a discontinuity in district BE provision at the 20-student cutoff, with districts above the cutoff having higher rates of BE provision. In order to examine this, in Figure 4, we plot the average share of schools that are in districts providing BE by the number of Spanish LEP students in the first grade cohort. Visually, there is a jump up at the 20-student cutoff. It is worth noting that there is not perfect adherence to the policy rule (had this been the case, 100 percent of districts would provide BE above the cutoff). One reason is that participation in BE requires parental consent, and many parents choose ESL for their child even when BE is available. What is measured in the data is whether the district actually does provide BE; we cannot observe when a district offers BE but there is zero take-up. A second reason is that it is difficult to recruit certified bilingual education teachers, and school districts are allowed to delay providing $\mathrm{BE}$ if they are unable to find a qualified $\mathrm{BE}$ teacher.

Next, to more formally assess whether this difference in BE provision below and above is statistically significant, we estimate Equation 2 . These first-stage results 
are reported in the first row of Panel B in Table 4 (for the "non-LEP, non-Spanish home language" sample), Table 5 (for the Spanish home language" sample) and Table 6 (for the "all students" sample). The coefficient for being above the cutoff is always positive and significant across the different samples. For the samples that pool third to fifth graders, we find that districts with more than 20 Spanish LEP students in the first grade cohort are about 28 percentage points more likely to offer bilingual education than districts below the cutoff. This is a sizable effect-a three-fold increase relative to the mean for district $\mathrm{BE}$ provision among the school-grade-year observations below the cutoff (which is 9 percent). Clearly, the policy rule generates sizable variation in district provision of bilingual education for a particular first grade cohort.

\section{Effect of Bilingual Education on "Non-LEP, Non-Spanish Home Language" Students}

Figure 5 provides visual evidence on the reduced-form relationship between district Spanish LEP count in the first grade cohort and "non-LEP, non-Spanish home language" student achievement for students in grades 3-5. The top three graphs show effects on math achievement, and the bottom three graphs show effects on reading achievement. For all outcomes we observe higher achievement among students in schools in districts above the cutoff, with especially pronounced increases for mean standardized test scores and mean share of students with commended performance.

Table 4 presents results from a formal evaluation of the achievement outcomes

around the cutoff, as described in Section III.B. Each cell of Table 4 represents a coefficient from a separate regression. In Columns 1 to 4, we provide results for math test outcomes from the pooled sample (Column 1), as well as separately for each grade (Columns 2 to 4 ). Columns 5 to 8 follow the same structure for reading test outcomes. Standard errors are clustered by district here, as in all the other regressions reported.

In Panel A, we report results from estimating the reduced-form relationship between student outcomes and the running variable, i.e. the coefficient estimates of $\delta_{R F}$ in Equation 3. The coefficient in the first row of Column 1 indicates that non-LEP 
students in schools in districts with at least 20 Spanish LEP students in the first grade cohort have a mean math standardized test score that is 0.059 standard deviations higher than non-LEP students in schools in districts with less than 20 Spanish LEP students in the first grade cohort. Similarly, the coefficient in the second (third) row of column (1) indicates that the math passing (commended) rate of non-LEP students is 0.984 (2.215) percentage points higher in schools in districts located to the right of the cutoff. The results based on separate regressions by grade also confirm positive effects on math test performance for non-LEP students in districts to the right of the cutoff, especially for standardized test score and commended rate. An examination of reading outcomes, provided in columns 5 to 8 of Panel A, also points to improved educational performance for non-LEP students in districts to the right of the cutoff, most notably for mean standardized reading test score. These results are in line with the graphical evidence presented above.

In Panel B of Table 3, we present results from the estimation of the first stage equation (Equation 2), followed by the results from our structural model (Equation 1) using Above20 to instrument for district provision of bilingual education. As discussed in Section V.C, the results reported in the first row of panel B indicate that the first stage relationship is strong and robust across all samples. The effect of bilingual education on non-LEP math outcomes are presented in rows 2 to 4 and columns 1 to 4 of panel B. The estimated effects are positive and generally statistically significant for mean math test score and mean math commended rate. For example, our estimates suggest that district $\mathrm{BE}$ provision causes an increase of about 0.213 standard deviations in the mean math achievement of non-LEP students (panel B, row 2, column 1). Similarly, the point estimate provided in row 4 and column 1 of panel B indicates that district $\mathrm{BE}$ provision increases the math commended rate by 7.987 percentage points - a 30 percent increase when compared to the mean commended rate among schools in districts below the cutoff. The point estimate on math passing rate from the pooled sample is also large, and points to a 5 percent increase relative to the mean among schools in districts below the cutoff, but it is imprecisely estimated. 
It is interesting that the impact on the commended rate is larger than the impact on the passing rate. The positive point estimates for both suggest that both students at the margin of failing/passing the exam, and at the margin of good/very good performance, are contributing to the measured increase in average math test scores due to district $\mathrm{BE}$ provision. Considering that the passing rate impacts are smaller in magnitude and typically not significant, it appears that the positive impact on math test score is largely driven by an improvement in the math test performance of higherachieving students. We return to this result in Section V.H when we consider potential mechanisms for these spillover effects.

The impact of BE programs on non-LEP students' reading outcomes are reported in columns 5 to 8 of Panel B. We again find that the estimated effects are mostly positive and economically large but they are generally smaller than the effects on math and have less statistical significance. For example, our results suggest that providing bilingual education causes an increase of about 0.17 standard deviations in the mean standardized reading achievement (panel B, row 2, column 5), and 5 percentage points in reading passing (panel B, row 3, column 5) and commended rates (panel B, row 4, column 5) of non-LEP non-Spanish home language students. It is worth noting that even though these 2SLS estimates are somewhat imprecise, and we cannot reject the null hypothesis that they are zero at conventional levels, we are able to reject relatively small negative effects on non-LEP students. The 95 percent confidence intervals for the for the pooled effect on standardized reading score is [$0.01,0.35]$, which means we can rule out district BE provision reducing standardized reading score by more than a hundredth of a standard deviation at the 5 percent significance level. For the reading passing rate, the 95 percent confidence interval for the pooled effect $[-1.57,11.59]$, which means we can rule out negative effects over 1.57 percentage points at the 5 percent significance level; 1.57 is less than 2 percent of the mean passing rate (of 83 percent) among the sample below the cutoff. Similarly, the 95 percent confidence intervals for the reading commended rate is $[-1.62,10.95]$, 
which means we can rule out district BE provision reducing reading commended rates by more than 1.62 percentage points at the 5 percent significance level.

Overall, the results presented in this section point to spillover effects of educational programs for LEP students on their non-LEP peers. Specifically, when we examine non-LEP, non-Spanish home language students-a group that represents the majority of students in the schools in our sample and that would not have participated in the LEP programs themselves - we find significant positive effects on academic performance. The positive effects of BE relative to ESL tend to be economically and statistically significant for math test performance. For reading test performance, the point estimates are positive though not significant at conventional levels, but we can rule out small negative effects with 95 percent confidence.

\section{E. Effect of Bilingual Education on "Spanish Home Language" Students}

Figure 6 plots the achievement outcomes for students who have Spanish as their home language in grades 3 to 5 as a function of the district-wide number of Spanish LEP students in the first grade cohort. The graphs show weak achievement

gains to the right of the cutoff, though the magnitude seems much smaller compared to that observed for non-LEP students, especially for the reading outcomes depicted in the bottom panel.

Table 5 presents the estimation results. The table is structured in the same way as Table 4. The reduced-form estimates, reported in Panel A, are generally small and always statistically insignificant. This confirms the visual evidence from Figure 6 of little change at the cutoff.

The results presented in rows 2 to 4 of Panel B provide causal effects of district $\mathrm{BE}$ provision on the standardized test performance of Spanish home language students. The 2SLS estimates on mean standardized achievement test scores from the pooled sample suggest that providing bilingual education is associated with a statistically insignificant increase of 0.107 standard deviations for math scores and 0.040 standard deviations for reading scores. However, we are able to reject modestly 
sized negative effects on test scores. The 95 percent confidence intervals for the standardized math and reading score among the pooled samples are $[-0.20,0.41]$ and $[-0.27,0.35]$, respectively. Thus, we can reject at the 5 percent significance level that district $\mathrm{BE}$ provision lowers mean math and reading scores by more than 0.2 and 0.3 standard deviations, respectively.

Our results also indicate statistically insignificant and economically small effects of BE provision on test passing rates. For example, we find in the pooled sample that BE programs increase (decrease) the math (reading) passing rate of Spanish home language students by 1.652 (0.509) percentage points (row 3, columns 1 and 5 , Panel B) or 2 percent $(<1$ percent) of the mean passing rate among the sample below the cutoff. While the results for the commended rate translate into economically large effects, the confidence intervals are also very large and thus do not allow us to rule out economically large negative effects.

As noted before, the Spanish home language students are comprised of currently LEP, previously LEP and never LEP students. Hence, our results do not directly provide estimates of the effect of district BE provision on Spanish home language students ever classified as LEP (and therefore potential participants in BE and ESL programs). ${ }^{25}$ Instead, they capture both the effect of district BE provision on the intended beneficiaries as well as spillover effects. Nevertheless, these results are informative because an overwhelming majority of students with Spanish as a home language are classified as LEP: in our sample, 89 percent of Spanish home language students are classified as LEP in first grade. Thus, these results roughly correspond to the intention-to-treat effect of bilingual education programs on intended beneficiaries. ${ }^{26}$ It is worth noting that these are not estimates of the effect of actually

\footnotetext{
${ }^{25} \mathrm{We}$ are unable to directly estimate this because we do not have separate test score data on students who are currently non-LEP but had previously been classified as LEP. While we do have data on Spanish home language students by current LEP status, we have chosen to combine them in order to avoid difficulties in interpreting results due to endogenous mainstreaming of students.

${ }^{26}$ Of course literally it is not, as it is a weighted average of the effect on ever-LEPs (the intended beneficiaries, who receive $89 \%$ weight) and the never-LEPs (who receive $11 \%$ weight). We can compute the effect on ever-LEPs under varying assumptions about the size of the effect for never-LEPs,
} 
participating in $\mathrm{BE}$; as we discussed above, whether a student takes up on $\mathrm{BE}$, conditional on being offered $\mathrm{BE}$, is endogenous, and we have no way to address this sort of selection into program participation so we cannot uncover the effect of BE on the BE participants themselves. ${ }^{27}$ However, as we also discussed above, the intentionto-treat effect is directly relevant for policy making.

Overall, these results indicate that while district BE provision does not significantly benefit Spanish home language students, it does not harm them either, at least in terms of test score achievements. Since the Spanish home language student sample is primarily composed of ever-LEP students, our results also indicate that the impact of bilingual education provision on the intended beneficiaries is generally positive though insignificant. This finding is consistent with the Slavin et al. (2010), Matsudaira (2005) and Angrist, Chin and Godoy (2008) studies discussed in Section II.B-LEP students' educational outcomes are not significantly different in bilingual programs compared to English-intensive programs.

\section{F. The Net Effect of Bilingual Education on Students}

Table 6 provides the results of estimating Equations 1-3 using the average test performance of all students combined. Arguably these net effects of district $\mathrm{BE}$ provision are the most relevant ones for policy making, as they weigh the test score gains and losses across all students equally. Even if in practice policy makers do not assign equal weights to each student-for example, to comply with U.S. civil rights laws, they might care more about the LEP students' educational progress-these estimates provide a benchmark to gauge the implicit efficiency gains or losses associated with a particular LEP program.

The reduced-form effects are shown in Panel A, and the first-stage and 2SLS

with the result that the effect for ever-LEPs will be positive except when the effect on never-LEPs is positive and incredibly large (e.g., one whole standard deviation for math test scores).

${ }^{27}$ If there were no spillover effects of $\mathrm{BE}$, then it might be possible to obtain the effect of treatment on the treated by scaling the intention-to-treat effect by the program take-up rate. This assumption seems difficult to justify, however, given that we do find evidence of spillover effects for the "non-LEP, nonSpanish home language" students. 
estimates are shown in Panel B. Considering that over three quarters of the students in our analysis samples are in the "non-LEP, non-Spanish home language" category, not surprisingly, the results in Table 6 consistently point to positive effects of district BE provision on student achievement, though the 2SLS estimates are significant only for mean standardized math achievement score and mean math commended rate. This positive net impact indicates that on average, the test score gains due to district $\mathrm{BE}$ provision exceed the test score losses experienced by students in a given cohort and school. That is, for the districts hovering around the 20-Spanish-LEP-student cutoff used in our analysis, provision of bilingual education actually led to net gains in student achievement without hurting either "Spanish home language" students as a group, or "non-LEP, non-Spanish home language" students as a group.

\section{G. Sensitivity Analysis}

In Table 7, we examine the robustness of our reduced form results to several potential concerns. Since our most novel contribution is investigating spillover effects of educational programs for LEP students, we present results using the "non-LEP nonSpanish home language" sample. ${ }^{28}$ Each cell shows the 2 SLS estimate of the effect of district BE provision from a separate regression based on the pooled sample of students in $3^{\text {rd }}$ to $5^{\text {th }}$ grades. Columns 1 to 3 provide results for math, and Columns 4-6 provide the results for reading. The first row reproduces the baseline 2SLS estimates for reference (see Panel B, Columns 1 and 5 of Table 4).

In rows 2 and 3 of Table 7, we check the sensitivity of the estimates to the way we have treated masked values in the data. As mentioned before, in our data, Spanish LEP student counts for a school-grade-year are masked if the number is between 1 and 4. This impacts our ability to measure the running variable, number of Spanish LEP students in the first grade cohort in the district, precisely. Our main analysis assigned

\footnotetext{
${ }^{28}$ We also perform the same robustness checks for the "Spanish home language" sample and the "all students" sample, and find that the results reported in Sections V.E and V.F stand. These additional tables are available from the authors.
} 
the average value of 2.5 students to those school-grade-year cells with masked value. In Row 2, we assign the minimum value of 1 student, and in Row 3, we assign the maximum value of 4 students, and observe that the 2SLS estimates of the effect of district BE provision are unchanged versus the baseline model.

Our baseline model assumes that the underlying relationship between student achievement and district-wide Spanish LEP student count in the first grade cohort is piecewise linear (we control for a linear function of district-wide Spanish LEP student count that allows for different slopes above and below the cutoff). To the extent that this functional form is misspecified, the RD design leads to a biased estimate of the treatment effect. Our choice of a piecewise linear function was guided by the graphs of academic achievement by Spanish LEP count (Figure 5 for "non-LEP, non-Spanish home language" students), which did not indicate nonlinearities in the underlying relationship. In rows 4 and 5 of Table 7, we test the sensitivity of our results to the assumed functional form of the running variable by choosing polynomials of different degrees. In row 4, when we use a quadratic smoother (i.e., we control for a quadratic function of Spanish LEP count that allows for different slopes above and below the cutoff), the point estimates still suggest a positive impact on student achievement. However, none of the coefficients are statistically significant because the standard errors are on average 1.6 times of those from the baseline model. The coefficient in row 4, column 1 indicates that district BE provision raises non-LEP, non-Spanish home language students' mean math achievement by 0.118 standard deviations; this coefficient is not significantly different from zero, though it can also be noted that its 95 percent confidence interval includes the 2SLS estimated effect of 0.213 found in the baseline model. When a cubic smoother is used (row 5), again none of the estimated effects are significant, though the point estimate indicates an effect of 0.117 standard deviations on mean math achievement.

In rows 6 and 7, we check the sensitivity of our estimates to the chosen bandwidth. Our main analysis was restricted to school-grade-year observations in districts with between 8 and 39 Spanish LEP students in the first grade cohort. In row 
5 , we restrict to observations in districts within a tighter range of the 20-Spanish-LEPstudent cutoff: 10 to 29. The sample size is reduced, resulting in larger standard errors, however the results are qualitatively similar to the baseline model. In row 6 , we expand the bandwidth to schools in districts with 8 to 49 Spanish LEP students in the first grade cohort and the results are again similar to the baseline model.

Next, we check the sensitivity of our estimates to the choice of school year for defining small school district. Our baseline estimates rely on observations from school districts with fewer than 200 students in 2004-05. We show that the results are robust when we change the "baseline" year and restrict the sample to school districts with fewer than 200 students in 2000-2001 (row 8) or in 2008-2009 (row 9).

In the last row of Table 7, we report estimates of the effects when we restrict the baseline sample to observations in school districts that had a single elementary school from 1998-99 to 2009-10. These schools are of interest to analyze for two reasons. First, they might be especially responsive to the policy rule because not only are they small in terms of student enrollment (by construction of our analysis samples, they have fewer than 200 students in the first grade cohort), also they have less ability to shift resources. Besides within school shifts, only shifts across school levels are possible (e.g., between elementary and secondary schools), but such shifts are likely less feasible than shifts across schools within the same level. Second, it is clearer what is happening in these single elementary school districts: district provision of $\mathrm{BE}$ means school provision of $\mathrm{BE}$ in that grade, and since there is no scope for students changing schools within the same district then unambiguously non-LEP students' exposure to LEP classmates above the cutoff decreases. ${ }^{29} 61$ percent of the observations in the full analysis sample are from single elementary school districts. Using this subsample, we find that the 2SLS effects are larger in magnitude and more

\footnotetext{
${ }^{29}$ For multiple elementary school districts, a non-LEP student's exposure to LEP classmates can increase or decrease above the cutoff depending on which school offers the BE program, and the extent to which students change schools on the basis of BE program location.
} 
statistically significant relative to the baseline results. ${ }^{30}$ Strikingly, significant positive impacts of district BE provision are found for both math and reading; in the baseline results, though the 2 SLS estimates of impact on reading performance were positive, typically they were not significant.

\section{H. Potential Mechanisms}

A priori, one may expect changes in school resource allocation to be an important mechanism for the effects of district bilingual education provision because $\mathrm{BE}$ programs cost more and state funding does not cover the incremental costs of $\mathrm{BE}$ in Texas. In this section, we estimate the effects of district BE provision on school resource allocations to see if there is empirical support for this mechanism. To perform this analysis, we start with the "non-LEP, non-Spanish home language" sample and merge in school resources data. Two caveats are in order. First, the resource variables are measured at the level of the school while the policy variation is at the level school-grade-year. ${ }^{31}$ Therefore, the resources analysis is rather crude, and misses within school, cross-grade shifts in resources. Second, the resources data are available only beginning in 2004-05. Thus we must restrict our analysis to the schoolgrade-year observations from 2006-07 and later. ${ }^{32}$

The results of estimating Equation 3 using the resource variables as the dependent variables are displayed in Table 8. Panel A presents results using all observations in the "non-LEP, non-Spanish home language" with non-missing

\footnotetext{
${ }^{30}$ The larger 2SLS estimates of district BE provision on academic achievement arise not from a lower effect on compliance rate (we find that the first-stage coefficients using the subsample of single-school districts are very similar in magnitude to those reported in Table 4), but from higher reduced-form effects.

${ }^{31}$ It would have been ideal to have these data at the school-grade-year level also, but such data are not available. We obtain the school-grade-year level dataset for analyzing the impact of district BE provision on school resources by merging in the resource data by school and first grade cohort. For example, an observation for third grade at given school in year $t$ is assigned the resource data for that school from year t-2 (when these third graders were in first grade). Hence observations with the same school and first grade cohort have the same resource variables, though their covariates differ.

32 The third graders in 2006-07 were first graders in 2004-05, the first year for which we have resource data. On the other hand, the last year for which test score data is 2009-10, so the last year of resource data we use is 2007-08.
} 
resources data. Panel B uses the subsample of observations from single elementary school districts.

Our earlier results indicated that district provision of BE significantly increases above the cutoff. Because BE programs tend to be more expensive than ESL programs, and especially because a school district mandated by the Texas policy rule to provide $\mathrm{BE}$ also tends to provide ESL, we expect an increase in spending on educational programs for LEP students above the cutoff. This is exactly what we find-in column 3, school per-pupil spending on bilingual programs (which is inclusive of expenditures for assessing LEP status as well as instructing LEP students) significantly increases. The Panel A, column 3 point estimate suggests that spending on BE programs increases by $\$ 76$, which is 65 percent of mean per pupil bilingual program expenditures and 1.6 percent of mean school per pupil expenditures. Thus, in schools where the first grade cohort has 20 or more Spanish LEP students, more money is allocated to resources designated for LEP students.

There is no significant jump in total program expenditures (column 1), indicating that net new revenues are not arriving to cover the incremental cost of providing BE. None of the components of total program spending, displayed in columns 2-6, show significant changes above the cutoff besides bilingual program spending, though the point estimates are suggestive of compositional changes. For example, above the cutoff, we observe modestly sized decreases in spending on compensatory education and special education, large increases in spending on gifted and talented programs. ${ }^{33}$ Furthermore, results in column 7 indicate no significant change in average class size in first grade above the cutoff. Based on these foregoing results, we conclude that a change in resource allocations does not appear to be an

\footnotetext{
${ }^{33}$ With regard to state funds for compensatory education programs, these funds are designated for provision of instruction or services to students at risk of dropping out of school (poor students and LEP students are among the at-risk groups), and the rule is that they are not to be used to fund regular programs or programs mandated by state law. Below the 20-student cutoff, schools might receive state funds for compensatory education to provide supplemental educational services, and above the cutoffwhen BE is mandated by state law-these funds decrease because BE encapsulates some of those services. To the extent that non-LEP at-risk students benefited from those compensatory programs typically used by LEP students, then BE provision could have negative effects for them.
} 
important mechanism driving our finding of positive spillover effects. Additionally, the fact that we obtain larger estimated effects of district BE provision for single elementary school districts relative to the full "non-LEP, non-Spanish home language" sample (compare rows 1 and 10 of Table 7) but the same reduced-form effects on school resources (compare the Panels A and B of Table 8), suggests that changes in school resource allocations do not account for the larger spillover effects in single elementary school districts.

Another mechanism that could explain our findings is changes in classroom composition. District BE provision reduces the number of LEP students in mainstream classes as LEP students in BE form their own separate classes. There could be peer effects of LEP classmates on LEP students. The finding of stronger effects for single elementary school districts is consistent with a peer effects story because in these districts, non-LEP students' exposure to LEP students unambiguously decreases above the cutoff (whereas the effect on exposure to LEP students can be less pronounced in districts with more elementary schools due to sorting of students across schools within the district in response to which school has the BE program). Corroborating the peer effects story is the finding of larger positive spillover effects for the math commended rate than the math passing rate. The larger effects on the commended rate relative to the passing rate suggest that higher achieving children gain more when $\mathrm{BE}$ is provided. This is consistent with direct peer effects (Imberman, Kugler and Sacerdote 2012, among others, have documented positive effects of having more high-achieving peers), as well as changes in classroom instruction (e.g., mainstream classes with fewer LEP students might cover more advanced academic content).

To summarize, we find that resources for non-LEP students do not increasein fact, there is evidence of crowd-out of resources for non-LEP students since BE program spending increases while overall program spending is unchanged-yet we observe positive effects on their academic achievement. The finding that non-LEP achievement can be raised without additional spending and without harming the achievement of the intended beneficiaries has important policy implications even if we 
cannot empirically pinpoint which specific peer effects story, or whether some other story, accounts for the observed positive spillover effects.

\section{Conclusion}

In this paper, we examine the effects of bilingual education programs (versus ESL programs alone) on the achievement of intended beneficiaries (LEP students) and their classmates (non-LEP students). In order to address potential bias due to the endogeneity of exposure to $\mathrm{BE}$, we exploit the plausibly exogenous variation in student exposure to BE generated by a policy rule in Texas. The policy rule requires that school districts provide BE when they have 20 or more LEP students in a particular elementary school grade and language. This motivates our identification strategy, which is a regression discontinuity (RD) design in which we compare student outcomes in districts that have slightly less than 20 LEP students in a language-grade to those with slightly more.

Using panel data from Texas public elementary schools, we find that district BE provision has significant positive effects on the standardized test scores of "nonLEP, non-Spanish home language" students, indicating the presence of spillover effects for educational programs for LEP students on non-LEP peers. We do not find significant effects on the academic performance of "Spanish home language" students, a group that is 89 percent ever-LEP students. On net for all students, the effects are positive and significant. An analysis of school spending data indicates that district BE provision does not significantly change school total per-pupil expenditures, but does significantly raise spending on programs exclusively for LEP students, thus changes in school spending cannot account for our finding of positive spillover effects. This finding is consistent with peer effects of LEP classmates on LEP students.

Given the high rates of low-skilled immigration in recent decades and the dispersion in settlement patterns of immigrants away from traditional immigrantreceiving areas, the issue of how to help LEP students is likely to keep its place at the center stage of education policy debates. Our results contribute to this debate by 
providing a convincing research design to evaluate the relative merits of BE programs compared to ESL programs alone-a question relevant to many school districts. While our findings are obtained in the context of smaller, less urban school districts in Texas, which may limit their external validity, nonetheless they have broad implications. In particular, any cost-benefit analysis on the value of LEP programs should take spillovers into account. In our context, BE programs provide more benefits than what the estimated effects on intended beneficiaries alone indicate, because these estimates ignore the benefits accruing to LEP students' peers. Although BE programs are adopted with the intention of helping LEP students, in our context it appears that the non-LEP students gain more from them, at least in terms of standardized test scores.

\section{REFERENCES}

Aizer, Anna. "Peer Effects and Human Capital Accumulation: The Externalities of ADD." NBER Working Paper No. 14354. Cambridge, MA: National Bureau of Economic Research, 2008.

Angrist, Joshua, Aimee Chin and Ricardo Godoy. "Is Spanish-only Schooling Responsible for the Puerto Rican Language Gap?" Journal of Development Economics 85(1-2) 2008: 105-128.

Angrist, Joshua and Kevin Lang. "Does Schooling Integration Generate Peer Effects? Evidence from Boston's Metco Program." American Economic Review, 94(5) 2004: 1613-1634.

Baker, K.A. and A.A. de Kanter. Effectiveness of Bilingual Educational: A Review of the Literature. Washington, D.C.: Office of Planning, Budget and Evaluation, U.S. Department of Education, 1981.

Betts, Julian R. "Educational Crowding Out: Do Immigrants Affect the Educational Attainment of American Minorities?" in Daniel S. Hamermesh and Frank D. Bean (eds.), Help or Hindrance? The Economic Implications of Immigration for African-Americans. New York: Russell Sage Foundation, 1998.

Carrell, Scott, and Mark Hoekstra. "Externalities in the Classroom: How Children Exposed to Domestic Violence Affect Everyone's Kids," American Economic Journal: Applied Economics, 2(1) 2010: 211-228. 
Cho, Rosa. "Are there Peer Effects Associated with Having English Language Learner (ELL) Classmates?: Evidence from the Early Childhood Longitudinal Study Kindergarten Cohort (ECLS-K).” Brown University, mimeo, 2011.

Crawford, James. Bilingual Education: History, Politics, Theory and Practice. Trenton, NJ: Crane Publishing Company, Inc., 1989.

Figlio, David. "Boys Named Sue: Disruptive Children and Their Peers." NBER Working Paper No. 11277. Cambridge, MA: National Bureau of Economic Research, 2005.

Geay, Charlotte, Sandra McNally and Shqiponja Telhaj. "Non-native Speakers of English in the Classroom: What are the Effects on Pupil Performance?" London School of Economics Centre for Economic Performance, mimeo, 2011.

Greene, Jay P. "A Meta-Analysis of the Effectiveness of Bilingual Education." Tomas Rivera Policy Institute, 1998.

Hanushek, Eric, John Kain, Jacob Markman, and Steven Rivkin. "Does Peer Ability Affect Student Achievement?" Journal of Applied Econometrics, 18(5) 2003: 527544.

Hoxby, Caroline M. "Do Immigrants Crowd Disadvantaged American Natives out of Higher Education?" in Daniel S. Hammermesh and Frank D. Bean (eds.), Help or Hindrance? The Economic Implications of Immigration for African-Americans. New York: Russell Sage Foundation, 1998.

Hoxby, Caroline and Gretchen Weingarth. "Taking Race Out of the Equation: School Reassignment and the Structure of Peer Effects." Presented at the 2006 American Economics Association Annual Meetings, 2006.

Imbens, Guido and Thomas Lemieux. "Regression Discontinuity Designs: A Guide to Practice." Journal of Econometrics, 142(2) 2008: 615 - 635.

Imberman, Scott, Adriana Kugler, and Bruce Sacerdote. "Katrina's Children: Evidence on the Structure of Peer Effects from Hurricane Evacuees." American Economic Review, 102(5) 2012.

Lavy, Victor, Daniele Paserman and Analia Schlosser. "Inside the Black Box of Ability Peer Effects: Evidence from Variation in High and Low Achievers in the Classroom." Economic Journal, 122(559) 2012: 208-237.

Lee, David S. and Thomas Lemieux. "Regression Discontinuity Designs in 
Economics." Journal of Economic Literature, 48(2) 2010: 281-355.

Liu, Samuel T. Essays on the Effects of Immigration on Education and Crime. Ph.D. thesis, MIT, 2000.

Matsudaira, Jordan D. "Sinking or Swimming? Evaluating the Impact of English Immersion versus Bilingual Education on Student Achievement." University of California, Berkeley, mimeo, 2005.

McCrary, Justin. "Manipulation of the Running Variable in the Regression Discontinuity Design: A Density Test." Journal of Econometrics, 142(2) 2008: 698-714.

National Clearinghouse for English Language Acquisition (NCELA). "The Growing Numbers of English Learner Students 1998/99-2008/09.” Washington DC: U.S. Department of Education Office of English Acquisition mini-poster, February 2011.

Neymotin, Florence. "Immigration and its Effect on the College-Going Outcomes of Natives." Economics of Education Review 28, 2009: 538-550.

Nieto, Diego. "A Brief History of Bilingual Education in the United States." Perspectives on Urban Education Spring 2009: 61-72.

Rossell, Christine H. and Keith Baker. "The Educational Effectiveness of Bilingual Education." Research in the Teaching of English 30 (February 1996a), 7-74.

Slavin, Robert E., Nancy Madden, Margarita Calderón, Anne Chamberlain and Megan Hennessy. "Reading and Language Outcomes of a Five-Year Randomized Evaluation of Transitional Bilingual Education." Educational Evaluation and Policy Analysis 33(1) 2011: 47-58.

U.S. Commission on Civil Rights, A Better Chance to Learn: Bilingual Bicultural Education, U.S. Commission on Civil Rights Clearinghouse Publication No. 51, 1975.

Willig, Ann C. "Meta-Analysis of Selected Studies on the Effectiveness of Bilingual Education." Review of Educational Research 55 (Fall 1985), 269-317.

Zehler, Annette M., Howard L. Fleischman, Paul J. Hopstock, Todd G. Stephenson, Michelle L. Pendzick and Saloni Sapru. Descriptive Study of Services to LEP Students and LEP Students with Disabilities, Volume IA Research Report-Text. Washington, DC: Department of Education, 2003. 
Figure 1: Texas School Districts with 8 - 39 Spanish LEP Students in the First Grade Cohort
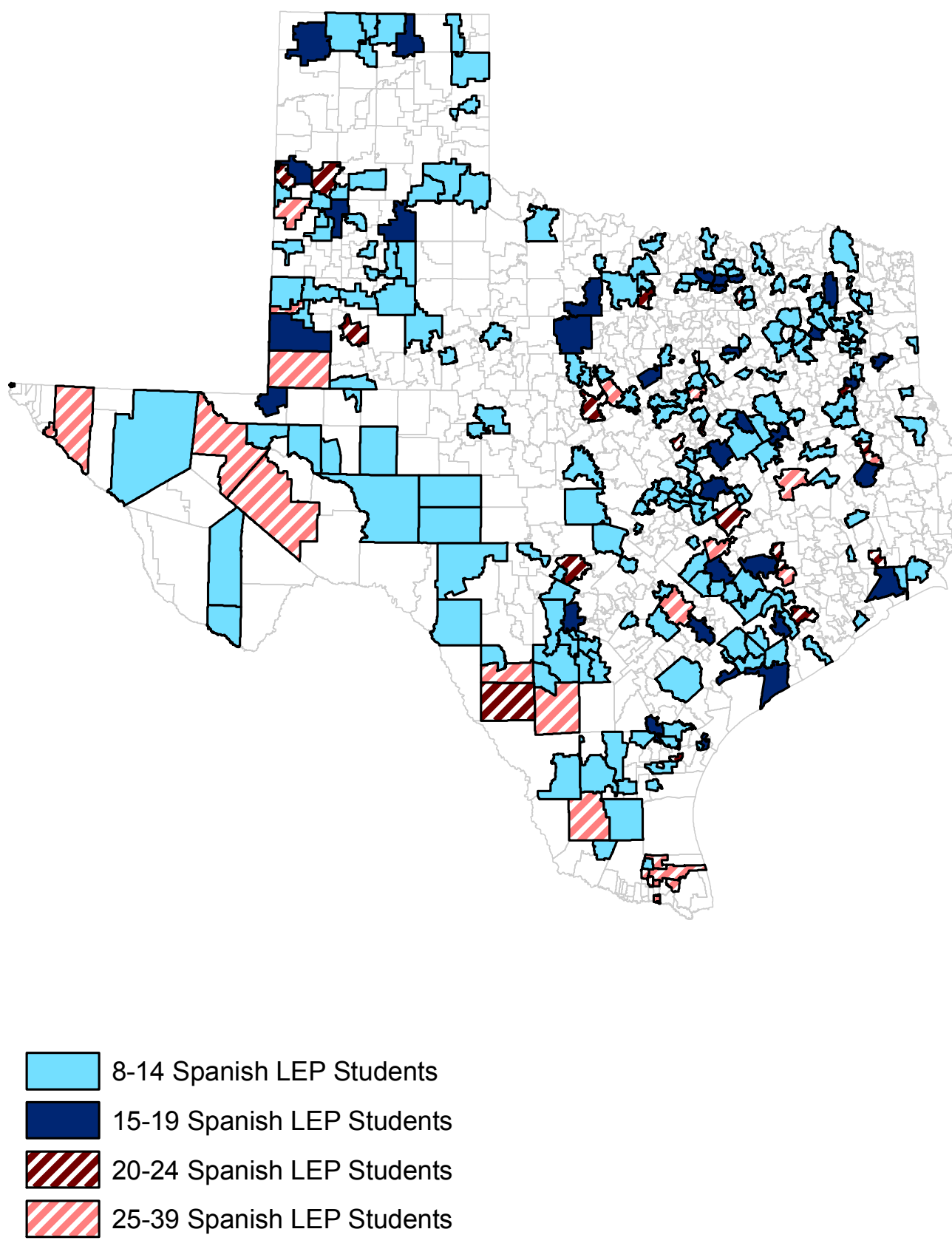

The shaded area corresponds to school districts with fewer than 200 students in the first grade cohort in 2004-05, and with between 8 and 39 Spanish LEP students in the first grade cohort on average between 2002-03 and 2009-10; this shaded area corresponds to the 261 districts present in the "non-LEP, non-Spanish language" sample described in Table 1. 
Figure 2: Distribution of District First Grade LEP Counts, 1998-99 through 2007-08

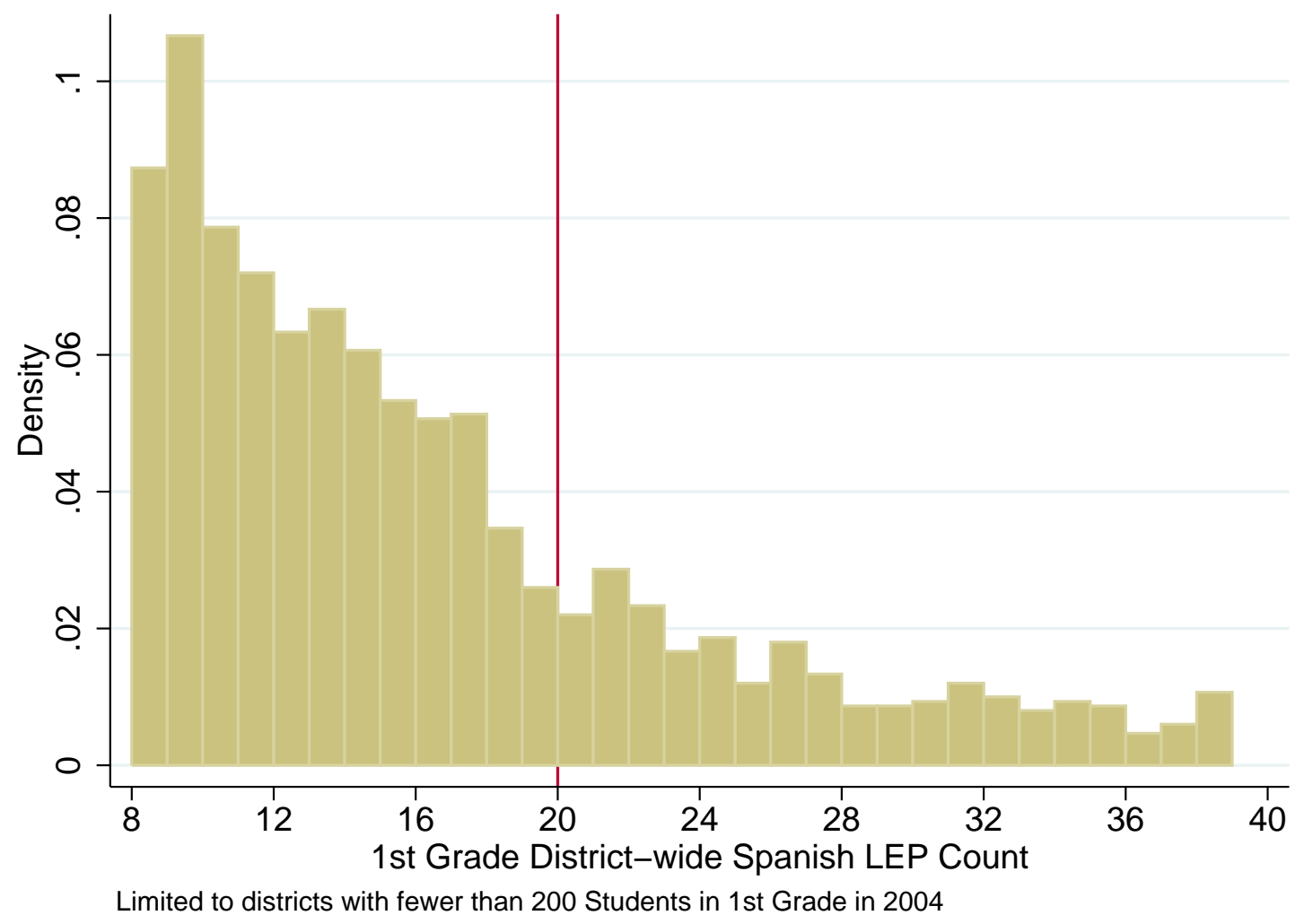

We use the years 1998-99 through 2007-08 because the $3^{\text {rd }}-5^{\text {th }}$ graders for whom we observe achievement outcomes in 2002-03 to 2009-10 map back to the first graders in 1998-99 to 2007-08. 

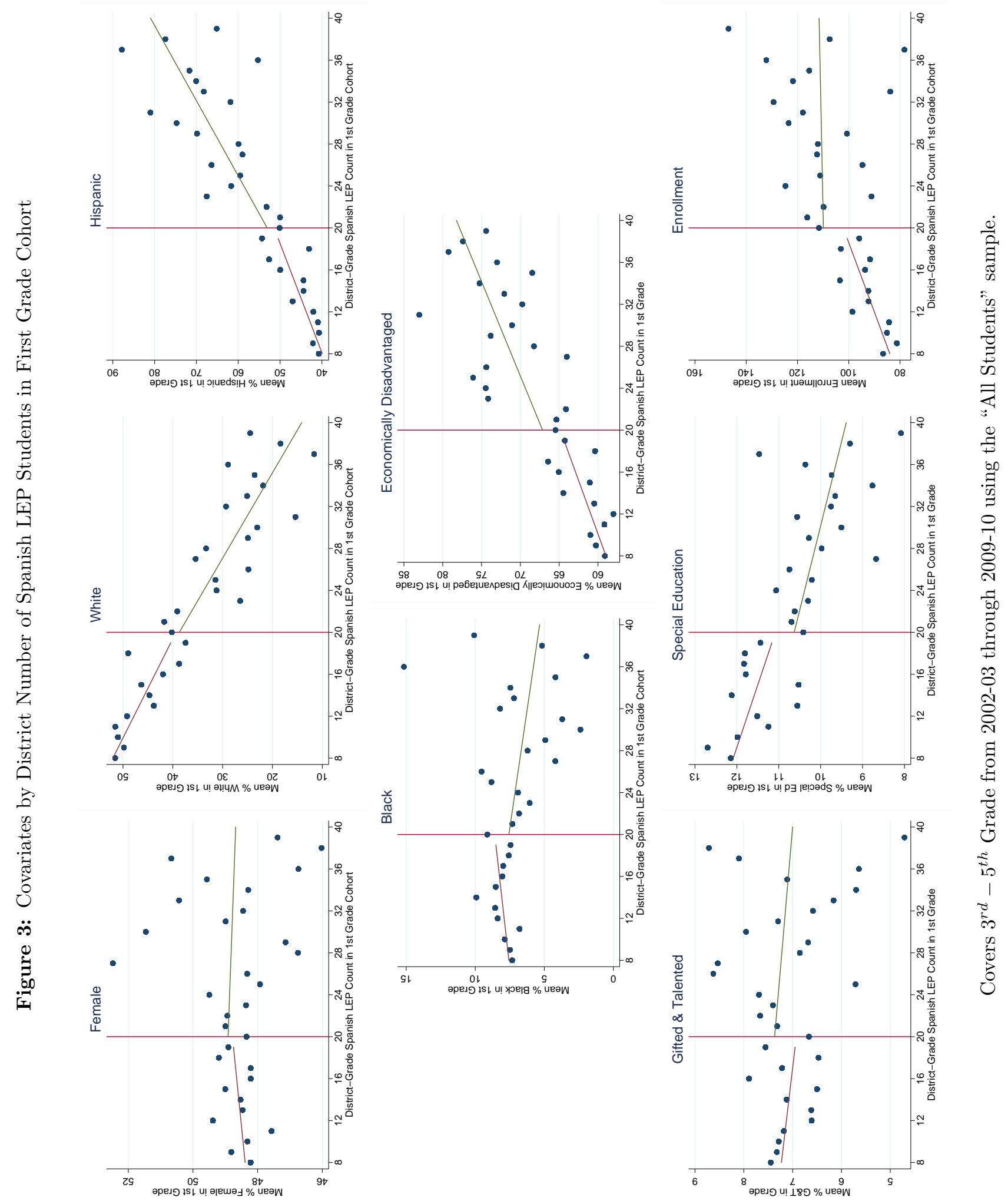
Figure 4: District Has a Bilingual Program in First Grade, 1998-99 through 2007-08

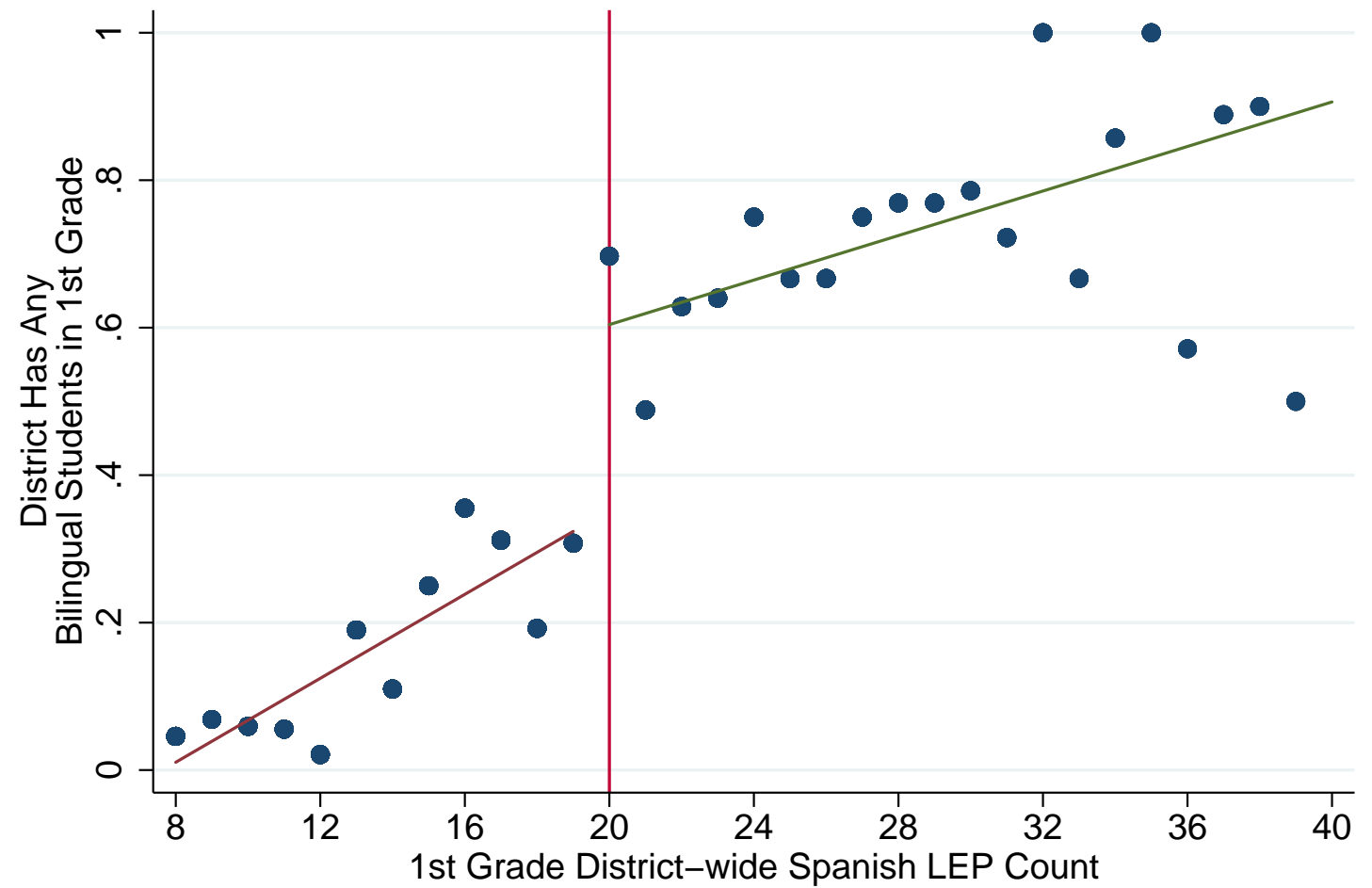

Limited to districts with fewer than 200 students in 1st Grade in 2004. The school-year is the unit of observation.

We use the years 1998-99 through 2007-08 because the $3^{\text {rd }}-5^{\text {th }}$ graders for whom we observe achievement outcomes in 2002-03 to 2009-10 map back to the first graders in 1998-99 to 2007-08. 

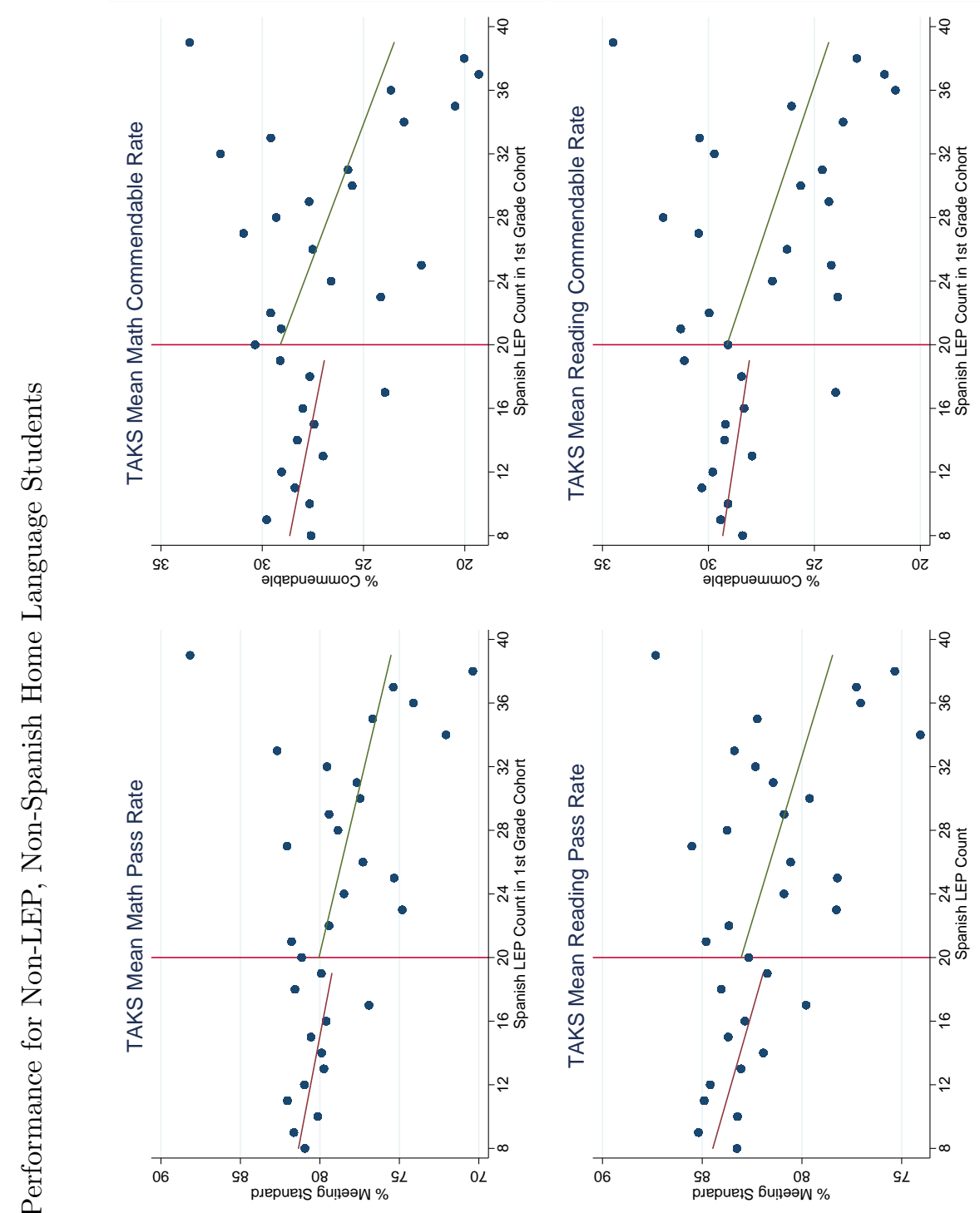

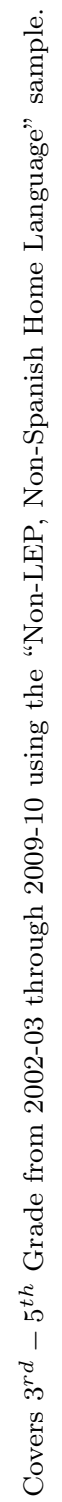




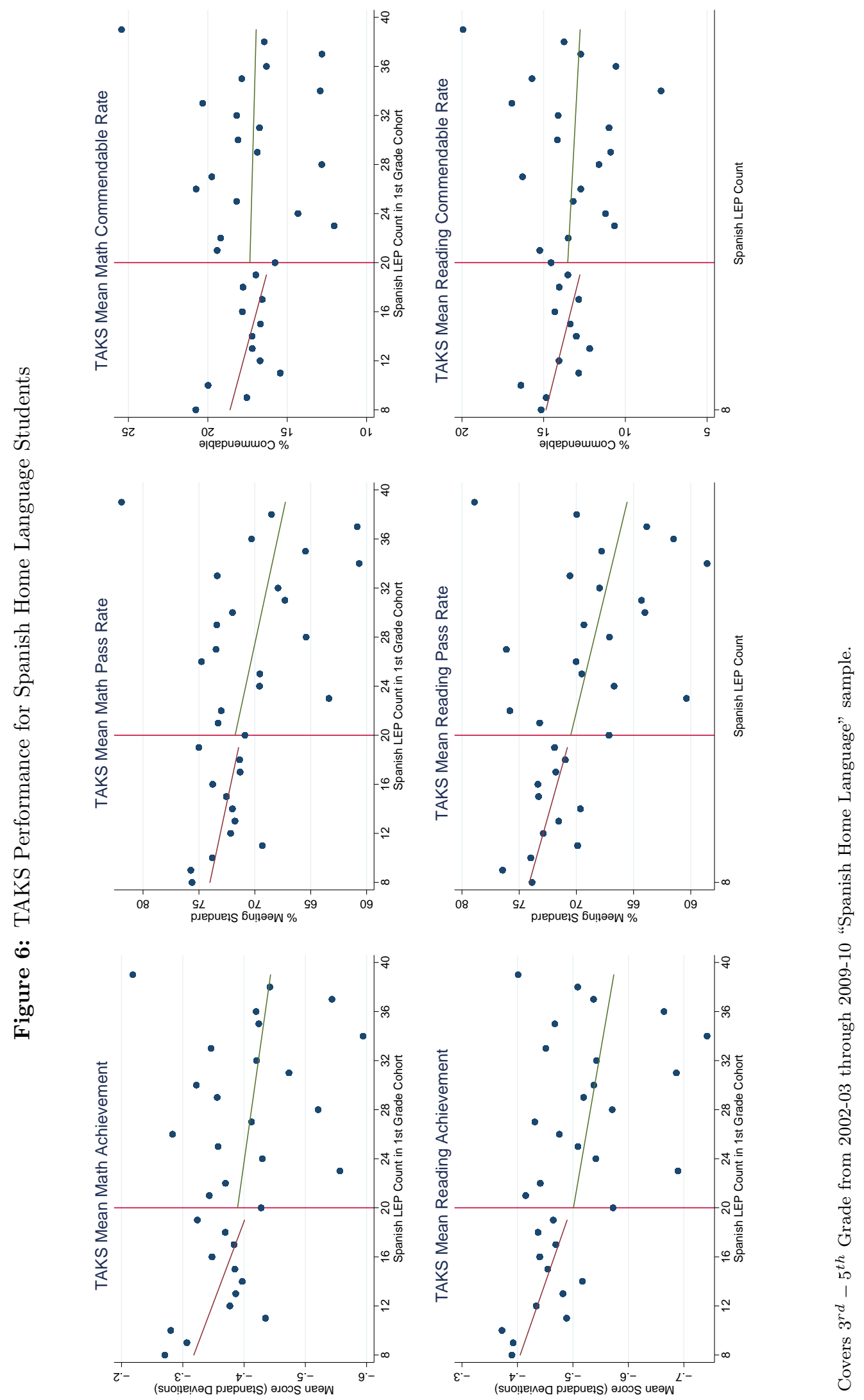


Table 1: Summary Statistics for "Non-LEP, Non-Spanish Home Language" Sample, 2002-03 through 2009-10

\begin{tabular}{|c|c|c|c|}
\hline & $\begin{array}{c}\text { Full Sample } \\
\text { (8 to } 39 \text { LEP in } 1 \text { st } \\
\text { Grade Cohort) }\end{array}$ & $\begin{array}{c}8 \text { to } 19 \text { LEP in } 1 \text { st } \\
\text { Grade Cohort }\end{array}$ & $\begin{array}{c}20 \text { to } 39 \text { LEP in } 1 \text { st } \\
\text { Grade Cohort }\end{array}$ \\
\hline \multicolumn{4}{|c|}{ Mean (Standard Deviation) Among All Students in Same School-Grade } \\
\hline$\%$ Female & $\begin{array}{l}48.6 \\
(6.0)\end{array}$ & $\begin{array}{l}48.5 \\
(6.1)\end{array}$ & $\begin{array}{l}48.8 \\
(5.6)\end{array}$ \\
\hline$\%$ White & $\begin{array}{c}43.7 \\
(24.5)\end{array}$ & $\begin{array}{l}47.8 \\
(23.6)\end{array}$ & $\begin{array}{c}31.2 \\
(23.1)\end{array}$ \\
\hline$\%$ Hispanic & $\begin{array}{l}48.0 \\
(27.0)\end{array}$ & $\begin{array}{l}43.6 \\
(25.4)\end{array}$ & $\begin{array}{l}61.5 \\
(27.4)\end{array}$ \\
\hline$\%$ Black & $\begin{array}{c}7.8 \\
(10.5)\end{array}$ & $\begin{array}{c}8.0 \\
(10.8)\end{array}$ & $\begin{array}{c}7.0 \\
(9.3)\end{array}$ \\
\hline$\%$ Economically Disadvantaged & $\begin{array}{c}63.1 \\
(17.8)\end{array}$ & $\begin{array}{c}60.8 \\
(17.3)\end{array}$ & $\begin{array}{c}70.4 \\
(17.3)\end{array}$ \\
\hline$\%$ LEP & $\begin{array}{c}11.7 \\
(10.3)\end{array}$ & $\begin{array}{l}10.3 \\
(9.0)\end{array}$ & $\begin{array}{c}16.1 \\
(12.4)\end{array}$ \\
\hline$\%$ in Bilingual Program & $\begin{array}{c}3.5 \\
(8.7)\end{array}$ & $\begin{array}{c}1.3 \\
(4.8)\end{array}$ & $\begin{array}{c}10.2 \\
(13.2)\end{array}$ \\
\hline$\%$ in Special Education Program & $\begin{array}{l}11.4 \\
(5.5)\end{array}$ & $\begin{array}{l}11.7 \\
(5.7)\end{array}$ & $\begin{array}{l}10.3 \\
(4.8)\end{array}$ \\
\hline$\%$ in Gifted and Talented Program & $\begin{array}{c}7.2 \\
(4.9)\end{array}$ & $\begin{array}{c}7.2 \\
(5.0)\end{array}$ & $\begin{array}{c}7.3 \\
(4.6)\end{array}$ \\
\hline \multicolumn{4}{|c|}{ Mean (S.D.) Among Non-LEP, Non-Spanish Home Language Students in Same School-Grade } \\
\hline TAKS Math Standardized Scale Score & $\begin{array}{l}-0.08 \\
(0.35)\end{array}$ & $\begin{array}{l}-0.07 \\
(0.36)\end{array}$ & $\begin{array}{l}-0.13 \\
(0.33)\end{array}$ \\
\hline TAKS Math Passing Rate & $\begin{array}{c}80.0 \\
(14.0)\end{array}$ & $\begin{array}{c}80.5 \\
(13.8)\end{array}$ & $\begin{array}{c}78.5 \\
(14.4)\end{array}$ \\
\hline TAKS Math Commended Rate & $\begin{array}{l}27.8 \\
(14.4)\end{array}$ & $\begin{array}{c}28.0 \\
(14.5)\end{array}$ & $\begin{array}{c}27.1 \\
(14.1)\end{array}$ \\
\hline TAKS Reading Standardized Scale Score & $\begin{array}{l}-0.03 \\
(0.32)\end{array}$ & $\begin{array}{l}-0.01 \\
(0.33)\end{array}$ & $\begin{array}{l}-0.08 \\
(0.30)\end{array}$ \\
\hline TAKS Reading Passing Rate & $\begin{array}{c}83.0 \\
(12.3)\end{array}$ & $\begin{array}{c}83.5 \\
(12.3)\end{array}$ & $\begin{array}{c}81.4 \\
(12.2)\end{array}$ \\
\hline TAKS Reading Commended Rate & $\begin{array}{l}28.5 \\
(13.9)\end{array}$ & $\begin{array}{c}28.8 \\
(14.1)\end{array}$ & $\begin{array}{c}27.4 \\
(13.2)\end{array}$ \\
\hline Observations (School-Grade-Year) & 3761 & 2835 & 926 \\
\hline \# of Schools & 413 & 375 & 148 \\
\hline \# of Districts & 261 & 247 & 89 \\
\hline
\end{tabular}

Notes: Each school-grade-year for grades 3 through 5 is a separate observation. Sample is limited to observations in districts with fewer than 200 students in the 1st grade cohort in 2004-05, in district-grade-years with between 8 and 39 LEP students in the 1st grade cohort, and with non-missing math or reading achievement variables. 
Table 2: OLS Estimates of Relationship Between District Bilingual Education Provision and TAKS Achievement

\begin{tabular}{|c|c|c|c|c|c|c|c|c|}
\hline & \multicolumn{4}{|c|}{ Math } & \multicolumn{4}{|c|}{ Reading } \\
\hline & $\begin{array}{l}\text { Pooled } \\
\text { (1) }\end{array}$ & $\begin{array}{c}\text { 3rd } \\
\text { Grade } \\
(2)\end{array}$ & $\begin{array}{c}\text { 4th } \\
\text { Grade } \\
\text { (3) }\end{array}$ & $\begin{array}{c}\text { 5th } \\
\text { Grade } \\
(4)\end{array}$ & $\begin{array}{l}\text { Pooled } \\
\text { (5) }\end{array}$ & $\begin{array}{c}\text { 3rd } \\
\text { Grade } \\
(6)\end{array}$ & $\begin{array}{c}\text { 4th } \\
\text { Grade } \\
(7)\end{array}$ & $\begin{array}{l}\text { 5th } \\
\text { Grade } \\
(8)\end{array}$ \\
\hline & \multicolumn{8}{|c|}{ A. "Non-LEP, Non-Spanish Home Language" Students } \\
\hline $\begin{array}{l}\text { Mean Standardized } \\
\text { Achievement }\end{array}$ & $\begin{array}{c}0.008 \\
(0.029)\end{array}$ & $\begin{array}{l}-0.014 \\
(0.036)\end{array}$ & $\begin{array}{c}0.021 \\
(0.038)\end{array}$ & $\begin{array}{c}0.020 \\
(0.033)\end{array}$ & $\begin{array}{c}0.006 \\
(0.026)\end{array}$ & $\begin{array}{l}-0.014 \\
(0.030)\end{array}$ & $\begin{array}{c}0.024 \\
(0.031)\end{array}$ & $\begin{array}{c}0.010 \\
(0.028)\end{array}$ \\
\hline Passing Rate & $\begin{array}{l}-0.257 \\
(1.057)\end{array}$ & $\begin{array}{l}-0.832 \\
(1.188)\end{array}$ & $\begin{array}{l}-0.390 \\
(1.250)\end{array}$ & $\begin{array}{c}0.617 \\
(1.342)\end{array}$ & $\begin{array}{l}-0.420 \\
(0.850)\end{array}$ & $\begin{array}{l}-1.479 * \\
(0.835)\end{array}$ & $\begin{array}{c}0.253 \\
(1.053)\end{array}$ & $\begin{array}{c}0.189 \\
(1.070)\end{array}$ \\
\hline Commended Rate & $\begin{array}{c}0.610 \\
(1.012)\end{array}$ & $\begin{array}{l}-0.223 \\
(1.256)\end{array}$ & $\begin{array}{c}1.287 \\
(1.446)\end{array}$ & $\begin{array}{c}0.950 \\
(1.098)\end{array}$ & $\begin{array}{c}0.531 \\
(0.866)\end{array}$ & $\begin{array}{c}0.234 \\
(1.199)\end{array}$ & $\begin{array}{c}0.471 \\
(0.950)\end{array}$ & $\begin{array}{c}0.885 \\
(0.822)\end{array}$ \\
\hline \multirow[t]{2}{*}{ Observations } & 3,759 & 1,291 & 1,246 & 1,222 & 3,761 & 1,291 & 1,246 & 1,224 \\
\hline & \multicolumn{8}{|c|}{ B. "Spanish Home Language" Students } \\
\hline $\begin{array}{l}\text { Mean Standardized } \\
\text { Achievement }\end{array}$ & $\begin{array}{l}-0.055 \\
(0.042)\end{array}$ & $\begin{array}{l}-0.036 \\
(0.044)\end{array}$ & $\begin{array}{l}-0.059 \\
(0.052)\end{array}$ & $\begin{array}{l}-0.074 \\
(0.047)\end{array}$ & $\begin{array}{l}-0.071 * \\
(0.042)\end{array}$ & $\begin{array}{l}-0.048 \\
(0.043)\end{array}$ & $\begin{array}{l}-0.087 * \\
(0.050)\end{array}$ & $\begin{array}{r}-0.082 * \\
(0.045)\end{array}$ \\
\hline Passing Rate & $\begin{array}{l}-1.677 \\
(1.835)\end{array}$ & $\begin{array}{l}-0.512 \\
(2.072)\end{array}$ & $\begin{array}{l}-2.116 \\
(2.189)\end{array}$ & $\begin{array}{l}-2.612 \\
(2.106)\end{array}$ & $\begin{array}{l}-3.076 * \\
(1.741)\end{array}$ & $\begin{array}{l}-1.738 \\
(1.650)\end{array}$ & $\begin{array}{l}-4.155^{*} \\
(2.199)\end{array}$ & $\begin{array}{l}-3.437 \\
(2.201)\end{array}$ \\
\hline Commended Rate & $\begin{array}{l}-2.015 * \\
(1.125)\end{array}$ & $\begin{array}{l}-1.444 \\
(1.252)\end{array}$ & $\begin{array}{l}-1.892 \\
(1.470)\end{array}$ & $\begin{array}{l}-2.795^{*} \\
(1.539)\end{array}$ & $\begin{array}{l}-1.128 \\
(1.046)\end{array}$ & $\begin{array}{l}-0.955 \\
(1.440)\end{array}$ & $\begin{array}{l}-1.373 \\
(1.246)\end{array}$ & $\begin{array}{l}-1.159 \\
(0.949)\end{array}$ \\
\hline \multirow[t]{2}{*}{ Observations } & 3,247 & 1,168 & 1,067 & 1,012 & 3,244 & 1,170 & 1,064 & 1,010 \\
\hline & \multicolumn{8}{|c|}{ C. All Students } \\
\hline $\begin{array}{l}\text { Mean Standardized } \\
\text { Achievement }\end{array}$ & $\begin{array}{l}-0.007 \\
(0.032)\end{array}$ & $\begin{array}{l}-0.012 \\
(0.037)\end{array}$ & $\begin{array}{l}-0.001 \\
(0.040)\end{array}$ & $\begin{array}{l}-0.006 \\
(0.035)\end{array}$ & $\begin{array}{l}-0.014 \\
(0.029)\end{array}$ & $\begin{array}{l}-0.015 \\
(0.031)\end{array}$ & $\begin{array}{l}-0.006 \\
(0.035)\end{array}$ & $\begin{array}{l}-0.019 \\
(0.030)\end{array}$ \\
\hline Passing Rate & $\begin{array}{l}-0.870 \\
(1.179)\end{array}$ & $\begin{array}{l}-0.680 \\
(1.370)\end{array}$ & $\begin{array}{l}-1.128 \\
(1.329)\end{array}$ & $\begin{array}{l}-0.747 \\
(1.432)\end{array}$ & $\begin{array}{l}-1.254 \\
(0.973)\end{array}$ & $\begin{array}{l}-1.420 \\
(0.913)\end{array}$ & $\begin{array}{l}-1.108 \\
(1.219)\end{array}$ & $\begin{array}{l}-1.121 \\
(1.227)\end{array}$ \\
\hline Commended Rate & $\begin{array}{c}0.302 \\
(1.035)\end{array}$ & $\begin{array}{l}-0.095 \\
(1.197)\end{array}$ & $\begin{array}{c}0.785 \\
(1.417)\end{array}$ & $\begin{array}{c}0.361 \\
(1.119)\end{array}$ & $\begin{array}{c}0.210 \\
(0.880)\end{array}$ & $\begin{array}{c}0.277 \\
(1.157)\end{array}$ & $\begin{array}{l}-0.056 \\
(0.999)\end{array}$ & $\begin{array}{c}0.421 \\
(0.768)\end{array}$ \\
\hline Observations & 3,819 & 1,314 & 1,266 & 1,239 & 3,819 & 1,314 & 1,266 & 1,239 \\
\hline
\end{tabular}

Notes: Observations are at the school-grade-year level, and cover the 2002-03 through 2009-10 school years. Sample is limited to observations in districts with fewer than 200 students in the 1st grade cohort in 2004-05, in district-grade-years with between 8 and 39 LEP students in the 1st grade cohort, and with non-missing achievement variables. The observations differ slightly across the panels because the incidence of masked achievement outcomes differs across the student categories. Each coefficient and associated standard error reported comes from a separate regression that also controls for grade-year fixed effects and the percent of all students in the school-grade-year who are female, economically disadvantaged, white, black and Hispanic.

Regressions in Panel A (Panel B) also control for the percent female and percent disadvantaged among "non-LEP, non-Spanish language" students ("Spanish home language" students). Standard errors clustered by district are in parentheses. *, ** and $* * *$ denote significance at the $10 \%, 5 \%$ and $1 \%$ levels, respectively. 
Table 3: Tests of Discontinuities in Covariates

A. Mean Covariate Among All Students in Same School-Grade-Year

\begin{tabular}{|c|c|c|c|c|c|c|c|c|c|}
\hline & \multicolumn{6}{|c|}{ Demographic Composition } & \multicolumn{2}{|c|}{ School Program Participation } & \multirow[b]{2}{*}{$\begin{array}{c}\text { Enrollment } \\
\text { (9) }\end{array}$} \\
\hline & $\begin{array}{c}\% \text { Female } \\
\text { (1) }\end{array}$ & $\begin{array}{c}\% \text { White } \\
\text { (2) }\end{array}$ & $\begin{array}{c}\% \text { Hispanic } \\
\text { (3) }\end{array}$ & $\begin{array}{c}\% \text { Black } \\
(4)\end{array}$ & $\begin{array}{c}\text { \% Disadv } \\
(8)\end{array}$ & $\begin{array}{c}\% \text { LEP } \\
(5)\end{array}$ & $\begin{array}{c}\% \text { Gifted } \\
(6)\end{array}$ & $\begin{array}{c}\% \text { SpecEd } \\
(7)\end{array}$ & \\
\hline 1st Grade Spanish LEP Count $>=20$ & $\begin{array}{c}0.092 \\
(0.657)\end{array}$ & $\begin{array}{l}-0.793 \\
(3.512)\end{array}$ & $\begin{array}{c}1.928 \\
(4.015)\end{array}$ & $\begin{array}{l}-1.148 \\
(1.619)\end{array}$ & $\begin{array}{c}2.333 \\
(2.660)\end{array}$ & $\begin{array}{c}0.237 \\
(1.638)\end{array}$ & $\begin{array}{c}0.554 \\
(0.536)\end{array}$ & $\begin{array}{l}-0.191 \\
(0.546)\end{array}$ & $\begin{array}{l}39.514 * \\
(20.728)\end{array}$ \\
\hline Observations & 3,819 & 3,819 & 3,819 & 3,819 & 3,819 & 3,819 & 3,819 & 3,819 & 3,819 \\
\hline
\end{tabular}

B. Mean Among "Non-LEP, Non-Spanish Home Language" Students Only

\begin{tabular}{|c|c|c|c|}
\hline & $\begin{array}{c}\% \text { Female } \\
\text { (1) }\end{array}$ & $\begin{array}{c}\% \text { Disadv } \\
\text { (3) }\end{array}$ & $\begin{array}{c}\% \text { Gifted } \\
\text { (2) }\end{array}$ \\
\hline 1st Grade Spanish LEP Count $>=20$ & $\begin{array}{c}0.469 \\
(0.801)\end{array}$ & $\begin{array}{c}2.888 \\
(3.008)\end{array}$ & $\begin{array}{c}0.468 \\
(0.695)\end{array}$ \\
\hline Observations & 3,761 & 3,761 & 3,761 \\
\hline Joint Significance Test (Prob $>$ Chi2) & & 0.54 & \\
\hline \multicolumn{4}{|c|}{ C. Mean Among "Spanish Home Language" Students Among } \\
\hline & $\begin{array}{c}\% \text { Female } \\
\text { (1) }\end{array}$ & $\begin{array}{c}\% \text { Disadv } \\
\text { (3) }\end{array}$ & $\begin{array}{c}\% \text { Gifted } \\
\text { (2) }\end{array}$ \\
\hline 1st Grade Spanish LEP Count $>=20$ & $\begin{array}{l}-1.734 \\
(1.299)\end{array}$ & $\begin{array}{c}1.258 \\
(1.316)\end{array}$ & $\begin{array}{c}0.584 \\
(0.899)\end{array}$ \\
\hline Observations & 3,262 & 3,262 & 3,262 \\
\hline
\end{tabular}

Notes: Observations are at the school-grade-year level, and cover the 2002-03 through 2009-10 school years. Observations are at the school-grade-year level, and cover the 2002-03 through 2009-10 school years. Sample is limited to observations in districts with fewer than 200 students in the 1st grade cohort in 2004-05, in district-grade-years with between 8 and 39 LEP students in the 1st grade cohort, and with non-missing achievement variables. Each coefficient and associated standard error reported comes from a separate regression that also controls for district-wide Spanish LEP count in the relevant 1 st grade cohort, district-wide LEP count interacted with a dummy for being above 20 Spanish LEP students, and grade-year fixed effects. Standard errors clustered by district are in parentheses. $* * *$ and $* * *$ denote significance at the $10 \%, 5 \%$ and $1 \%$ levels, respectively. 


\begin{tabular}{|c|c|c|c|c|c|c|c|}
\hline \multicolumn{4}{|c|}{ Math } & \multicolumn{4}{|c|}{ Reading } \\
\hline $\begin{array}{l}\text { Pooled } \\
\text { (1) }\end{array}$ & $\begin{array}{l}\text { 3rd Grade } \\
\text { (2) }\end{array}$ & $\begin{array}{l}\text { 4th Grade } \\
\text { (3) }\end{array}$ & $\begin{array}{l}\text { 5th Grade } \\
\text { (4) }\end{array}$ & $\begin{array}{l}\text { Pooled } \\
\text { (5) }\end{array}$ & $\begin{array}{l}\text { 3rd Grade } \\
\text { (6) }\end{array}$ & $\begin{array}{l}\text { 4th Grade } \\
\text { (7) }\end{array}$ & $\begin{array}{c}\text { 5th Grade } \\
\text { (8) }\end{array}$ \\
\hline
\end{tabular}

Mean Standardized Achievement

Passing Rate

Commended Rate

1st Stage, OLS coefficient for

1st Grade LEP Count > $=20$

2nd Stage - Mean Standardized Achievement

2nd Stage - Passing Rate

2nd Stage - Commended Rate

Observations

A. Reduced Form - OLS Coefficient for "District Has >=20 Spanish LEP Students in 1st Grade Cohort"

$\begin{array}{cccccccc}0.059^{* *} & 0.069^{*} & 0.028 & 0.085^{* *} & 0.046^{*} & 0.059^{*} & 0.025 & 0.056^{*} \\ (0.029) & (0.037) & (0.036) & (0.038) & (0.025) & (0.033) & (0.030) & (0.029) \\ 0.984 & 1.407 & -0.608 & 2.478 & 1.378 & 1.362 & 1.243 & 1.736 \\ (1.007) & (1.375) & (1.211) & (1.548) & (0.874) & (1.059) & (1.139) & (1.174) \\ 2.215^{* *} & 2.083^{*} & 1.836 & 2.911^{* *} & 1.283 & 2.267 * & 0.473 & 0.936 \\ (1.075) & (1.245) & (1.425) & (1.294) & (0.894) & (1.308) & (1.048) & (1.006)\end{array}$

B. 2SLS - Endogenous Regressor is "District has Any Bilingual Program in 1st Grade Cohort"

$\begin{array}{cccccccc}0.277 * * * & 0.256^{* * *} & 0.280^{* * *} & 0.296^{* * *} & 0.275^{* * *} & 0.276^{* * *} & 0.300^{* * *} & 0.294^{* * *} \\ (0.057) & (0.060) & (0.062) & (0.060) & (0.057) & (0.065) & (0.070) & (0.074) \\ 0.213^{*} & 0.268^{*} & 0.102 & 0.288^{*} & 0.169^{*} & 0.225 & 0.025 & 0.081 \\ (0.114) & (0.152) & (0.129) & (0.149) & (0.092) & (0.180) & (0.162) & (0.167) \\ 3.547 & 5.505 & -2.176 & 8.377 & 5.010 & 5.650 & 2.654 & 2.745 \\ (3.714) & (5.425) & (4.359) & (5.715) & (3.356) & (5.189) & (5.596) & (5.967) \\ 7.987 * * & 8.149 & 6.568 & 9.840 * & 4.666 & 8.200 & -0.608 & -0.344 \\ (4.050) & (4.979) & (5.025) & (5.012) & (3.206) & (6.787) & (5.063) & (4.883) \\ 3,759 & 1,291 & 1,246 & 1,222 & 3,761 & 1,291 & 1,246 & 1,224\end{array}$

Notes: Observations are at the school-grade-year level, and cover the 2002-03 through 2009-10 school years. Observations are at the school-grade-year level, and cover the 2002-03 through 2009-10 school years. Sample is limited to observations in districts with fewer than 200 students in the 1st grade cohort in 2004-05, in district-grade-years with between 8 and 39 LEP students in the 1st grade cohort, and with non-missing achievement variables. Each coefficient and associated standard error reported comes from a separate regression that also controls for district-wide Spanish LEP count in the relevant 1st grade cohort, district-wide LEP count interacted with a dummy for being above 20 Spanish LEP students, grade-year fixed effects, the percent of the school-grade-year overall who are female, economically disadvantaged, white, black and Hispanic, and the percent of "non-LEP, non-Spanish home language" students in a school-grade-year who are female or economically disadvantaged. Standard errors clustered by district are in parentheses. *, ** and *** denote significance at the $10 \%, 5 \%$ and $1 \%$ levels, respectively. 


\begin{tabular}{|c|c|c|c|c|c|c|c|c|}
\hline & \multicolumn{4}{|c|}{ Math } & \multicolumn{4}{|c|}{ Reading } \\
\hline & $\begin{array}{l}\text { Pooled } \\
\text { (1) }\end{array}$ & $\begin{array}{c}\text { 3rd Grade } \\
\text { (2) }\end{array}$ & $\begin{array}{c}\text { 4th Grade } \\
\text { (3) }\end{array}$ & $\begin{array}{c}\text { 5th Grade } \\
\text { (4) }\end{array}$ & $\begin{array}{l}\text { Pooled } \\
\text { (5) }\end{array}$ & $\begin{array}{c}\text { 3rd Grade } \\
\text { (6) }\end{array}$ & $\begin{array}{c}\text { 4th Grade } \\
\text { (7) }\end{array}$ & $\begin{array}{c}\text { 5th Grade } \\
\text { (8) }\end{array}$ \\
\hline & \multicolumn{8}{|c|}{ A. Reduced Form - OLS Coefficient for "District Has >=20 Spanish LEP Students in 1st Grade Cohort" } \\
\hline Mean Standardized Achievement & $\begin{array}{c}0.030 \\
(0.043)\end{array}$ & $\begin{array}{c}0.053 \\
(0.052)\end{array}$ & $\begin{array}{l}-0.015 \\
(0.054)\end{array}$ & $\begin{array}{c}0.050 \\
(0.054)\end{array}$ & $\begin{array}{c}0.011 \\
(0.043)\end{array}$ & $\begin{array}{c}0.025 \\
(0.049)\end{array}$ & $\begin{array}{c}-0.012 \\
(0.054)\end{array}$ & $\begin{array}{c}0.017 \\
(0.056)\end{array}$ \\
\hline Passing Rate & $\begin{array}{c}0.455 \\
(2.047)\end{array}$ & $\begin{array}{c}2.220 \\
(2.646)\end{array}$ & $\begin{array}{l}-2.406 \\
(2.439)\end{array}$ & $\begin{array}{c}1.294 \\
(2.508)\end{array}$ & $\begin{array}{c}-0.141 \\
(1.891)\end{array}$ & $\begin{array}{c}-0.463 \\
(1.956)\end{array}$ & $\begin{array}{c}-0.857 \\
(2.377)\end{array}$ & $\begin{array}{c}0.952 \\
(2.663)\end{array}$ \\
\hline \multirow[t]{2}{*}{ Commended Rate } & $\begin{array}{c}0.954 \\
(1.313)\end{array}$ & $\begin{array}{c}0.896 \\
(1.401)\end{array}$ & $\begin{array}{c}0.305 \\
(1.784)\end{array}$ & $\begin{array}{c}1.842 \\
(2.004)\end{array}$ & $\begin{array}{c}0.848 \\
(1.222)\end{array}$ & $\begin{array}{c}2.396 \\
(1.882)\end{array}$ & $\begin{array}{c}0.529 \\
(1.397)\end{array}$ & $\begin{array}{c}-0.787 \\
(1.332)\end{array}$ \\
\hline & \multicolumn{8}{|c|}{ B. 2SLS - Endogenous Regressor is "District has Any Bilingual Program in 1st Grade Cohort" } \\
\hline $\begin{array}{l}\text { 1st Stage, OLS coefficient for } \\
\text { 1st Grade LEP Count }>=20\end{array}$ & $\begin{array}{c}0.276 * * * \\
(0.052)\end{array}$ & $\begin{array}{l}0.279 * * * \\
(0.052)\end{array}$ & $\begin{array}{c}0.270 * * * \\
(0.057)\end{array}$ & $\begin{array}{c}0.273 * * * \\
(0.059)\end{array}$ & $\begin{array}{c}0.277 * * * \\
(0.052)\end{array}$ & $\begin{array}{c}0.282 * * * \\
(0.052)\end{array}$ & $\begin{array}{c}0.276 * * * \\
(0.057)\end{array}$ & $\begin{array}{c}0.269 * * * \\
(0.059)\end{array}$ \\
\hline 2nd Stage - Mean Standardized Achievement & $\begin{array}{c}0.107 \\
(0.155)\end{array}$ & $\begin{array}{c}0.190 \\
(0.184)\end{array}$ & $\begin{array}{l}-0.056 \\
(0.200)\end{array}$ & $\begin{array}{c}0.182 \\
(0.202)\end{array}$ & $\begin{array}{c}0.040 \\
(0.156)\end{array}$ & $\begin{array}{c}0.088 \\
(0.171)\end{array}$ & $\begin{array}{l}-0.044 \\
(0.197)\end{array}$ & $\begin{array}{c}0.064 \\
(0.208)\end{array}$ \\
\hline 2nd Stage - Passing Rate & $\begin{array}{c}1.652 \\
(7.368)\end{array}$ & $\begin{array}{c}7.964 \\
(9.273)\end{array}$ & $\begin{array}{l}-8.897 \\
(9.503)\end{array}$ & $\begin{array}{c}4.735 \\
(9.147)\end{array}$ & $\begin{array}{l}-0.509 \\
(6.830)\end{array}$ & $\begin{array}{l}-1.644 \\
(6.970)\end{array}$ & $\begin{array}{l}-3.099 \\
(8.666)\end{array}$ & $\begin{array}{c}3.537 \\
(9.910)\end{array}$ \\
\hline 2nd Stage - Commended Rate & $\begin{array}{c}3.462 \\
(4.761)\end{array}$ & $\begin{array}{c}3.215 \\
(4.969)\end{array}$ & $\begin{array}{c}1.129 \\
(6.589)\end{array}$ & $\begin{array}{c}6.739 \\
(7.514)\end{array}$ & $\begin{array}{c}3.058 \\
(4.316)\end{array}$ & $\begin{array}{c}8.503 \\
(6.516)\end{array}$ & $\begin{array}{c}1.912 \\
(4.963)\end{array}$ & $\begin{array}{l}-2.922 \\
(5.018)\end{array}$ \\
\hline Observations & 3,247 & 1,168 & 1,067 & 1,012 & 3,244 & 1,170 & 1,064 & 1,010 \\
\hline
\end{tabular}

Notes: Observations are at the school-grade-year level, and cover the 2002-03 through 2009-10 school years. Observations are at the school-grade-year level, and cover the 2002-03 through 2009-10 school years. Sample is limited to observations in districts with fewer than 200 students in the 1st grade cohort in 2004-05, in district-grade-years with between 8 and 39 LEP students in the 1st grade cohort, and with non-missing achievement variables. Each coefficient and associated standard error reported comes from a separate regression that also controls for district-wide Spanish LEP count in the relevant 1st grade cohort, district-wide LEP count interacted with a dummy for being above 20 Spanish LEP students, grade-year fixed effects, the percent of the school-grade-year overall who are female, economically disadvantaged, white, black and Hispanic, and the percent of "Spanish home language" students in a school-grade-year who are female or economically disadvantaged. Standard errors clustered by district are in parentheses. *, ** and *** denote significance at the $10 \%, 5 \%$ and $1 \%$ levels, respectively. 


\begin{tabular}{|c|c|c|c|c|c|c|c|c|}
\hline & \multicolumn{4}{|c|}{ Math } & \multicolumn{4}{|c|}{ Reading } \\
\hline & $\begin{array}{l}\text { Pooled } \\
\text { (1) }\end{array}$ & $\begin{array}{c}\text { 3rd Grade } \\
\text { (2) }\end{array}$ & $\begin{array}{c}\text { 4th Grade } \\
\text { (3) }\end{array}$ & $\begin{array}{c}\text { 5th Grade } \\
\text { (4) }\end{array}$ & $\begin{array}{l}\text { Pooled } \\
\text { (5) }\end{array}$ & $\begin{array}{c}\text { 3rd Grade } \\
\text { (6) }\end{array}$ & $\begin{array}{l}\text { 4th Grade } \\
\text { (7) }\end{array}$ & $\begin{array}{c}\text { 5th Grade } \\
\text { (8) }\end{array}$ \\
\hline & \multicolumn{8}{|c|}{ A. Reduced Form - OLS Coefficient for "District Has >=20 Spanish LEP Students in 1st Grade Cohort" } \\
\hline Mean Standardized Achievement & $\begin{array}{l}0.056^{*} \\
(0.029)\end{array}$ & $\begin{array}{l}0.068 * \\
(0.036)\end{array}$ & $\begin{array}{c}0.015 \\
(0.035)\end{array}$ & $\begin{array}{c}0.090 * * \\
(0.036)\end{array}$ & $\begin{array}{c}0.039 \\
(0.026)\end{array}$ & $\begin{array}{c}0.049 \\
(0.032)\end{array}$ & $\begin{array}{c}0.010 \\
(0.029)\end{array}$ & $\begin{array}{l}0.057 * \\
(0.032)\end{array}$ \\
\hline Passing Rate & $\begin{array}{c}0.880 \\
(1.063)\end{array}$ & $\begin{array}{c}1.581 \\
(1.449)\end{array}$ & $\begin{array}{l}-1.333 \\
(1.227)\end{array}$ & $\begin{array}{l}2.684 * \\
(1.486)\end{array}$ & $\begin{array}{c}1.015 \\
(0.955)\end{array}$ & $\begin{array}{c}0.829 \\
(1.058)\end{array}$ & $\begin{array}{c}0.367 \\
(1.135)\end{array}$ & $\begin{array}{c}2.018 \\
(1.358)\end{array}$ \\
\hline \multirow[t]{2}{*}{ Commended Rate } & $\begin{array}{c}2.211 * * \\
(1.006)\end{array}$ & $\begin{array}{l}1.926 * \\
(1.105)\end{array}$ & $\begin{array}{c}1.598 \\
(1.353)\end{array}$ & $\begin{array}{c}3.297 * * * \\
(1.269)\end{array}$ & $\begin{array}{c}1.313 \\
(0.859)\end{array}$ & $\begin{array}{l}2.320 * \\
(1.206)\end{array}$ & $\begin{array}{c}0.358 \\
(0.947)\end{array}$ & $\begin{array}{c}1.070 \\
(0.920)\end{array}$ \\
\hline & \multicolumn{8}{|c|}{ B. 2SLS - Endogenous Regressor is "District has Any Bilingual Program in 1st Grade Cohort" } \\
\hline $\begin{array}{l}\text { 1st Stage, OLS coefficient for } \\
\text { 1st Grade LEP Count }>=20\end{array}$ & $\begin{array}{c}0.272 * * * \\
(0.058)\end{array}$ & $\begin{array}{l}0.251 * * * \\
(0.061)\end{array}$ & $\begin{array}{c}0.282 * * * \\
(0.063)\end{array}$ & $\begin{array}{l}0.282 * * * \\
(0.061)\end{array}$ & $\begin{array}{l}0.272 * * * \\
(0.058)\end{array}$ & $\begin{array}{c}0.268 * * * \\
(0.065)\end{array}$ & $\begin{array}{c}0.295 * * * \\
(0.069)\end{array}$ & $\begin{array}{c}0.286 * * * \\
(0.072)\end{array}$ \\
\hline 2nd Stage - Mean Standardized Achievement & $\begin{array}{l}0.206^{*} \\
(0.112)\end{array}$ & $\begin{array}{l}0.270 * \\
(0.150)\end{array}$ & $\begin{array}{c}0.052 \\
(0.123)\end{array}$ & $\begin{array}{l}0.320 * * \\
(0.155)\end{array}$ & $\begin{array}{c}0.143 \\
(0.095)\end{array}$ & $\begin{array}{c}0.178 \\
(0.181)\end{array}$ & $\begin{array}{l}-0.004 \\
(0.165)\end{array}$ & $\begin{array}{c}0.085 \\
(0.173)\end{array}$ \\
\hline 2nd Stage - Passing Rate & $\begin{array}{c}3.232 \\
(3.946)\end{array}$ & $\begin{array}{c}6.297 \\
(5.840)\end{array}$ & $\begin{array}{l}-4.722 \\
(4.508)\end{array}$ & $\begin{array}{c}9.520 \\
(5.885)\end{array}$ & $\begin{array}{c}3.727 \\
(3.576)\end{array}$ & $\begin{array}{c}3.374 \\
(5.317)\end{array}$ & $\begin{array}{c}0.333 \\
(5.613)\end{array}$ & $\begin{array}{c}3.579 \\
(6.484)\end{array}$ \\
\hline 2nd Stage - Commended Rate & $\begin{array}{l}8.124 * * \\
(3.802)\end{array}$ & $\begin{array}{l}7.670 * \\
(4.448)\end{array}$ & $\begin{array}{c}5.659 \\
(4.654)\end{array}$ & $\begin{array}{l}11.691 * * \\
(5.232)\end{array}$ & $\begin{array}{c}4.826 \\
(3.050)\end{array}$ & $\begin{array}{c}8.146 \\
(6.743)\end{array}$ & $\begin{array}{l}-0.067 \\
(5.017)\end{array}$ & $\begin{array}{c}0.160 \\
(4.722)\end{array}$ \\
\hline Observations & 3,819 & 1,314 & 1,266 & 1,239 & 3,819 & 1,314 & 1,266 & 1,239 \\
\hline
\end{tabular}

Notes: Observations are at the school-grade-year level, and cover the 2002-03 through 2009-10 school years. Observations are at the school-grade-year level, and cover the 2002-03 through 2009-10 school years. Sample is limited to observations in districts with fewer than 200 students in the 1st grade cohort in 2004-05, in district-grade-years with between 8 and 39 LEP students in the 1st grade cohort, and with non-missing achievement variables. Each coefficient and associated standard error reported comes from a separate regression that also controls for district-wide Spanish LEP count in the relevant 1st grade cohort, district-wide LEP count interacted with a dummy for being above 20 Spanish LEP students, grade-year fixed effects, and the percent of the school-grade-year overall who

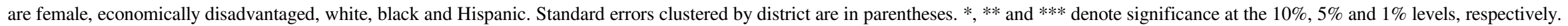


Table 7: Sensitivity Analysis of 2SLS Estimates of Effects on "Non-LEP, Non-Spanish Home Language" Students, Pooled Grades 3 - 5

\begin{tabular}{|c|c|c|c|c|c|c|}
\hline & \multicolumn{3}{|c|}{ Math } & \multicolumn{3}{|c|}{ Reading } \\
\hline & $\begin{array}{c}\text { Mean } \\
\text { Achievement } \\
\text { (1) }\end{array}$ & $\begin{array}{c}\text { Passing Rate } \\
\text { (2) }\end{array}$ & $\begin{array}{c}\text { Commended } \\
\text { Rate } \\
\text { (3) }\end{array}$ & $\begin{array}{c}\text { Mean } \\
\text { Achievement } \\
\text { (4) }\end{array}$ & $\begin{array}{c}\text { Passing Rate } \\
\text { (5) }\end{array}$ & $\begin{array}{c}\text { Commended } \\
\text { Rate } \\
\text { (6) }\end{array}$ \\
\hline \multicolumn{7}{|c|}{ 1) Baseline (From Table 4) } \\
\hline $\begin{array}{l}\text { District } \\
\text { Provides BE }\end{array}$ & $\begin{array}{l}0.213 * \\
(0.114)\end{array}$ & $\begin{array}{c}3.547 \\
(3.714)\end{array}$ & $\begin{array}{l}7.987 * * \\
(4.050)\end{array}$ & $\begin{array}{l}0.169 * \\
(0.092)\end{array}$ & $\begin{array}{c}5.010 \\
(3.356)\end{array}$ & $\begin{array}{c}4.666 \\
(3.206)\end{array}$ \\
\hline Observations & 3,759 & 3,759 & 3,759 & 3,761 & 3,761 & 3,761 \\
\hline \multicolumn{7}{|c|}{ 2) Assign Masked Values with 1 Student } \\
\hline $\begin{array}{l}\text { District } \\
\text { Provides BE }\end{array}$ & $\begin{array}{l}0.201 * \\
(0.116)\end{array}$ & $\begin{array}{c}3.132 \\
(3.706)\end{array}$ & $\begin{array}{l}7.656^{*} \\
(4.147)\end{array}$ & $\begin{array}{c}0.150 \\
(0.095)\end{array}$ & $\begin{array}{c}4.398 \\
(3.314)\end{array}$ & $\begin{array}{c}4.074 \\
(3.341)\end{array}$ \\
\hline Observations & 3,759 & 3,759 & 3,759 & 3,761 & 3,761 & 3,761 \\
\hline \multicolumn{7}{|c|}{ 3) Assign Masked Values with 4 Students } \\
\hline $\begin{array}{l}\text { District } \\
\text { Provides BE }\end{array}$ & $\begin{array}{l}0.211^{*} \\
(0.113)\end{array}$ & $\begin{array}{c}3.504 \\
(3.677)\end{array}$ & $\begin{array}{l}7.931 * * \\
(4.021)\end{array}$ & $\begin{array}{l}0.170 * \\
(0.092)\end{array}$ & $\begin{array}{c}5.080 \\
(3.345)\end{array}$ & $\begin{array}{c}4.715 \\
(3.196)\end{array}$ \\
\hline Observations & 3,759 & 3,759 & 3,759 & 3,761 & 3,761 & 3,761 \\
\hline \multicolumn{7}{|c|}{ 4) Quadratic Smoother } \\
\hline $\begin{array}{l}\text { District } \\
\text { Provides BE }\end{array}$ & $\begin{array}{c}0.118 \\
(0.194)\end{array}$ & $\begin{array}{c}1.065 \\
(5.737)\end{array}$ & $\begin{array}{c}1.396 \\
(6.684)\end{array}$ & $\begin{array}{c}0.114 \\
(0.148)\end{array}$ & $\begin{array}{c}4.304 \\
(5.305)\end{array}$ & $\begin{array}{c}3.041 \\
(5.342)\end{array}$ \\
\hline Observations & 3,759 & 3,759 & 3,759 & 3,761 & 3,761 & 3,761 \\
\hline \multicolumn{7}{|l|}{ 5) Cubic Smoother } \\
\hline $\begin{array}{l}\text { District } \\
\text { Provides BE }\end{array}$ & $\begin{array}{c}0.117 \\
(0.201)\end{array}$ & $\begin{array}{c}2.594 \\
(5.930)\end{array}$ & $\begin{array}{l}-0.250 \\
(6.225)\end{array}$ & $\begin{array}{c}0.006 \\
(0.140)\end{array}$ & $\begin{array}{c}2.563 \\
(5.446)\end{array}$ & $\begin{array}{l}-2.401 \\
(4.835)\end{array}$ \\
\hline Observations & 3,759 & 3,759 & 3,759 & 3,761 & 3,761 & 3,761 \\
\hline \multicolumn{7}{|c|}{ 6) Bandwidth of 10 to 29} \\
\hline $\begin{array}{l}\text { District } \\
\text { Provides BE }\end{array}$ & $\begin{array}{c}0.151 \\
(0.134)\end{array}$ & $\begin{array}{c}1.979 \\
(4.206)\end{array}$ & $\begin{array}{c}4.829 \\
(4.810)\end{array}$ & $\begin{array}{c}0.151 \\
(0.107)\end{array}$ & $\begin{array}{c}3.782 \\
(3.652)\end{array}$ & $\begin{array}{c}5.500 \\
(3.752)\end{array}$ \\
\hline Observations & 2,738 & 2,738 & 2,738 & 2,740 & 2,740 & 2,740 \\
\hline \multicolumn{7}{|c|}{ 7) Bandwidth of 8 to 49} \\
\hline $\begin{array}{l}\text { District } \\
\text { Provides BE }\end{array}$ & $\begin{array}{l}0.221^{*} \\
(0.118)\end{array}$ & $\begin{array}{l}8.394 * * \\
(4.006)\end{array}$ & $\begin{array}{l}8.394 * * \\
(4.006)\end{array}$ & $\begin{array}{l}0.158 * \\
(0.090)\end{array}$ & $\begin{array}{c}4.328 \\
(3.299)\end{array}$ & $\begin{array}{c}4.928 \\
(3.033)\end{array}$ \\
\hline Observations & 3,899 & 3,899 & 3,899 & 3,901 & 3,901 & 3,901 \\
\hline \multicolumn{7}{|c|}{ 8) Restrict to Districts with Fewer than 200 Students in 1st Grade in 2000 instead of 2004} \\
\hline $\begin{array}{l}\text { District } \\
\text { Provides BE }\end{array}$ & $\begin{array}{l}0.176^{*} \\
(0.103)\end{array}$ & $\begin{array}{c}2.461 \\
(3.499)\end{array}$ & $\begin{array}{l}7.301 * * \\
(3.516)\end{array}$ & $\begin{array}{c}0.120 \\
(0.080)\end{array}$ & $\begin{array}{c}3.024 \\
(2.866)\end{array}$ & $\begin{array}{c}3.974 \\
(2.764)\end{array}$ \\
\hline Observations & 4,119 & 4,119 & 4,119 & 4,121 & 4,121 & 4,121 \\
\hline \multicolumn{7}{|c|}{ 9) Restrict to Districts with Fewer than 200 Students in 1st Grade in 2008 instead of 2004} \\
\hline $\begin{array}{l}\text { District } \\
\text { Provides BE }\end{array}$ & $\begin{array}{c}0.161 \\
(0.109)\end{array}$ & $\begin{array}{c}1.813 \\
(3.564)\end{array}$ & $\begin{array}{l}6.476^{*} \\
(3.701)\end{array}$ & $\begin{array}{c}0.137 \\
(0.083)\end{array}$ & $\begin{array}{c}3.520 \\
(3.024)\end{array}$ & $\begin{array}{c}4.429 \\
(2.876)\end{array}$ \\
\hline Observations & 3,757 & 3,757 & 3,757 & 3,759 & 3,759 & 3,759 \\
\hline \multicolumn{7}{|c|}{ 10) Restrict to Districts with a Single Elementary School } \\
\hline $\begin{array}{l}\text { District } \\
\text { Provides BE }\end{array}$ & $\begin{array}{c}0.374 * * \\
(0.152)\end{array}$ & $\begin{array}{l}9.878 * \\
(5.008)\end{array}$ & $\begin{array}{c}12.062 * * \\
(5.356)\end{array}$ & $\begin{array}{c}0.374 * * * \\
(0.134)\end{array}$ & $\begin{array}{c}11.781 * * * \\
(4.399)\end{array}$ & $\begin{array}{c}10.109 * * \\
(4.486)\end{array}$ \\
\hline Observations & 2,296 & 2,296 & 2,296 & 2,298 & 2,298 & 2,298 \\
\hline
\end{tabular}

Notes: See Table 4 notes regarding base sample and specification. Reported is the 2SLS coefficient for the endogenous regressor, ""District has Any Bilingual Program in 1st Grade Cohort" where the identifying instrument is "District Has >=20 Spanish LEP Students in 1st Grade Cohort". Standard errors clustered by district are in parentheses. *,** and *** denote significance at the $10 \%, 5 \%$ and $1 \%$ levels, respectively. 
Table 8: Tests of Discontinuities in Per-Pupil Expenditures and Class Size

\begin{tabular}{|c|c|c|c|c|c|c|c|}
\hline & \multicolumn{6}{|c|}{ Per-Pupil Expenditures (in \$) } & \multirow[b]{2}{*}{$\begin{array}{c}\text { 1st Grade } \\
\text { Average Class } \\
\text { Size } \\
\text { (7) }\end{array}$} \\
\hline & $\begin{array}{c}\text { All Programs } \\
\text { (1) }\end{array}$ & $\begin{array}{l}\text { Regular } \\
\text { Program } \\
\quad(2)\end{array}$ & $\begin{array}{l}\text { Bilingual } \\
\text { Program } \\
\text { (3) }\end{array}$ & $\begin{array}{l}\text { Gifted and } \\
\text { Talented } \\
\text { Program } \\
\text { (4) }\end{array}$ & $\begin{array}{l}\text { Compensatory } \\
\text { Education } \\
\text { Program } \\
\text { (5) }\end{array}$ & $\begin{array}{c}\text { Special } \\
\text { Education } \\
\text { Program } \\
\text { (6) }\end{array}$ & \\
\hline & \multicolumn{7}{|c|}{ A. All Observations in "Non-LEP, Non-Spanish Home Language" Sample } \\
\hline Sample Mean & 4715 & 2983 & 117 & 31 & 1121 & 524 & 17.8 \\
\hline 1st Grade Spanish LEP Count $>=20$ & $\begin{array}{c}218.4 \\
(172.7)\end{array}$ & $\begin{array}{c}143.5 \\
(130.0)\end{array}$ & $\begin{array}{l}76.1^{* *} \\
(33.0)\end{array}$ & $\begin{array}{l}13.2 \\
(8.5)\end{array}$ & $\begin{array}{l}-59.6 \\
(90.1)\end{array}$ & $\begin{array}{l}-36.2 \\
(44.9)\end{array}$ & $\begin{array}{l}-0.303 \\
(0.439)\end{array}$ \\
\hline \multirow[t]{2}{*}{ Observations } & 962 & 947 & 947 & 947 & 947 & 947 & 937 \\
\hline & \multicolumn{7}{|c|}{ B. Restrict to Districts with a Single Elementary School } \\
\hline Sample Mean & 4784 & 2926 & 131 & 30 & 1188 & 519 & 17.7 \\
\hline 1st Grade Spanish LEP Count $>=20$ & $\begin{array}{c}-55.0 \\
(204.4)\end{array}$ & $\begin{array}{c}103.1 \\
(181.0)\end{array}$ & $\begin{array}{l}89.0 * \\
(48.2)\end{array}$ & $\begin{array}{c}1.1 \\
(8.0)\end{array}$ & $\begin{array}{l}-127.7 \\
(103.7)\end{array}$ & $\begin{array}{l}-72.8 \\
(57.3)\end{array}$ & $\begin{array}{c}0.196 \\
(0.510)\end{array}$ \\
\hline Observations & 565 & 562 & 562 & 562 & 562 & 562 & 559 \\
\hline $\begin{array}{l}\text { Notes: Observations are at the school-grade- } \\
\text { school and cohort have the same resource va } \\
2004-05 \text { and later, the school-grade-year obs } \\
\text { 2007-08). Observations are at the school-gra } \\
\text { students in the } 1 \text { st grade cohort in 2004-05, } \\
\text { coefficient reported comes from a separate r } \\
\text { a dummy for being above } 20 \text { Spanish LEP st } \\
\text { and Hispanic, and the percent of "non-LEP, } \\
\text { by district are in parentheses. *** and *** }\end{array}$ & $\begin{array}{l}\text { ir level. The resou } \\
\text { bles (though they } 1 \\
\text { ations in this anal } \\
\text {-year level, and co } \\
\text { listrict-grade-years } \\
\text { ession that also co } \\
\text { ents, grade-year fir } \\
\text { a-Spanish home la }\end{array}$ & $\begin{array}{l}\text { s cover } 2006 \\
\text { the } 2002-03 \\
\text { ith between } \\
\text { ols for distri } \\
\text { effects, the } \\
\text { uage" studen }\end{array}$ & $\begin{array}{l}\text { sured at the s } \\
\text { ates, as these } \\
\text { 2009-10 sch } \\
\text { ugh 2009-10s } \\
39 \text { LEP stude } \\
\text { de Spanish LF } \\
\text { nt of the scho } \\
\text { a school-grade }\end{array}$ & $\begin{array}{l}\text { level for the } \\
\text { by grade and } \\
\text { ears (which m } \\
1 \text { years. Samp } \\
n \text { the } 1 \text { st grade } \\
\text { unt in the rele } \\
\text { ade-year over }\end{array}$ & $\begin{array}{l}\text { elevant 1st grade c } \\
\text { st grade cohort). A } \\
\text { p back to the the f } \\
\text { e is limited to obse } \\
\text { cohort, and with n } \\
\text { ant 1st grade coho } \\
11 \text { who are female, } \\
\text { le or economically }\end{array}$ & $\begin{array}{l}\text { ort, hence obse } \\
\text { he resources di } \\
\text { t grade cohorts } \\
\text { ations in distri } \\
\text {-missing achie } \\
\text { district-wide I } \\
\text { onomically dis }\end{array}$ & $\begin{array}{l}\text { ons from the same } \\
\text { e available only in } \\
\text { 004-05 through } \\
\text { ith fewer than } 200 \\
\text { nt variables. Each } \\
\text { ount interacted with } \\
\text { ntaged, white, black } \\
\text { ard errors clustered }\end{array}$ \\
\hline
\end{tabular}

